\title{
Synthesis of $\left[\mathrm{Mo}_{3} \mathrm{~S}_{4}\right]$ Clusters from Half-Sandwich Mo(V) Chlorides and Their Application as Platforms for $\left[\mathrm{Mo}_{3} \mathrm{~S}_{4} \mathrm{Fe}\right]$ Cubes
}

Yasuhiro Ohki, * Ryota Hara, Kenichiro Munakata, Mizuki Tada, Tsutomu Takayama, Yoichi Sakai, and Roger E. Cramer

\section{Contents of the Supporting Information}

${ }^{1} \mathrm{H}$ NMR spectra of $\left(\mathrm{C}_{5} \mathrm{Me}_{4} \mathrm{SiMe}_{3}\right) \mathrm{MoCl}_{4}(\mathbf{1 a})$ and $\left(\mathrm{C}_{5} \mathrm{Me}_{4} \mathrm{SiEt}_{3}\right) \mathrm{MoCl}_{4}(\mathbf{1 b})$ in $\mathrm{CDCl}_{3} \quad \mathrm{~S} 3$

NMR spectra and the GC-MS chart of $\mathrm{C}_{5} \mathrm{Me}_{4} \mathrm{SiEt}_{3} \mathrm{H}$

S4-S5

X-band ESR spectra of $\left(\mathrm{C}_{5} \mathrm{Me}_{4} \mathrm{SiMe}_{3}\right) \mathrm{MoCl}_{4}(\mathbf{1 a}),\left(\mathrm{C}_{5} \mathrm{Me}_{4} \mathrm{SiEt}_{3}\right) \mathrm{MoCl}_{4}(\mathbf{1 b})$, and $\left(\mathrm{C}_{5} \mathrm{Me}_{4} \mathrm{H}\right) \mathrm{MoCl}_{4}$

(1c) in $\mathrm{CH}_{2} \mathrm{Cl}_{2}$

S6

Consideration of the residual electron densities in the crystal analysis of $\mathbf{1 b}$

S6-S7

${ }^{1} \mathrm{H}$ NMR spectra of the reaction mixtures of $\mathrm{Cp}^{\mathrm{R}} \mathrm{MoCl}_{4}(\mathbf{1 a - 1})+\mathrm{LiS}^{t} \mathrm{Bu}(4$ eq. $) \quad$ S7-S8

Molecular structure of $\left(\mathrm{C}_{5} \mathrm{Me}_{4} \mathrm{H}\right) \mathrm{Mo}\left(\mathrm{S}^{t} \mathrm{Bu}\right)_{3}(\mathbf{2 c})$

S9

Molecular structure of one of the byproducts $\left(\mathrm{C}_{5} \mathrm{Me}_{4} \mathrm{H}\right)_{2} \mathrm{Mo}_{2}(\mu-\mathrm{S})_{2}\left(\mu-\mathrm{S}{ }^{t} \mathrm{Bu}\right)_{2}$ (A), which was obtained from $1 \mathbf{c}+\mathrm{LiS}^{t} \mathrm{Bu}$

Molecular structure of one of the byproducts $\left[\left(\mathrm{C}_{5} \mathrm{Me}_{4} \mathrm{H}\right)_{4} \mathrm{Mo}_{4} \mathrm{~S}_{4}\right]\left[\mathrm{PF}_{6}\right](\mathbf{B})$, which was obtained from $\mathbf{1 c}+\mathrm{KC}_{8}+\mathrm{Li}_{2} \mathrm{~S}_{2}$ S10

$\mathrm{NMR}$ spectra of $\left[\left(\mathrm{C}_{5} \mathrm{Me}_{4} \mathrm{SiMe}_{3}\right)_{3} \mathrm{Mo}_{3} \mathrm{~S}_{4}\right]\left[\mathrm{PF}_{6}\right] \quad$ (3a), $\quad\left[\left(\mathrm{C}_{5} \mathrm{Me}_{4} \mathrm{SiEt}_{3}\right)_{3} \mathrm{Mo}_{3} \mathrm{~S}_{4}\right]\left[\mathrm{PF}_{6}\right] \quad$ (3b), and $\left[\left(\mathrm{C}_{5} \mathrm{Me}_{4} \mathrm{H}\right)_{3} \mathrm{Mo}_{3} \mathrm{~S}_{4}\right]\left[\mathrm{PF}_{6}\right](\mathbf{3 c})$ in $\mathrm{CDCl}_{3}$. 
${ }^{1} \mathrm{H}$ NMR spectra of $\left(\mathrm{C}_{5} \mathrm{Me}_{4} \mathrm{SiMe}_{3}\right)_{3} \mathrm{Mo}_{3} \mathrm{~S}_{4}(\mathbf{4 a}),\left(\mathrm{C}_{5} \mathrm{Me}_{4} \mathrm{SiEt}_{3}\right)_{3} \mathrm{Mo}_{3} \mathrm{~S}_{4}(\mathbf{4 b})$, and $\left(\mathrm{C}_{5} \mathrm{Me} \mathrm{H}_{4} \mathrm{H}\right)_{3} \mathrm{Mo}_{3} \mathrm{~S}_{4}$ (4c) in $\mathrm{C}_{6} \mathrm{D}_{6}$ S19-20

Molecular structure of a cubane-type cluster $\left(\mathrm{C}_{5} \mathrm{Me}_{4} \mathrm{SiEt}_{3}\right)_{3} \mathrm{Mo}_{3} \mathrm{~S}_{4} \mathrm{FeCl}(\mathbf{5 b})$ S20

${ }^{1} \mathrm{H}$ NMR spectra of $\mathbf{5 a}$ and $\mathbf{5 b}$ in $\mathrm{C}_{6} \mathrm{D}_{6}$ S21

Cyclic voltammograms of $\mathbf{5 a}$ and $\mathbf{5 b}$ in THF at room temperature S22

ESI-MS spectra of $\mathbf{5 a}$ and $\mathbf{5 b}$ in THF S23-S24

Mössbauer spectra of polycrystalline $\mathbf{5 a}$ and $\mathbf{5 b}$ at zero-field and $78 \mathrm{~K}$ S25 

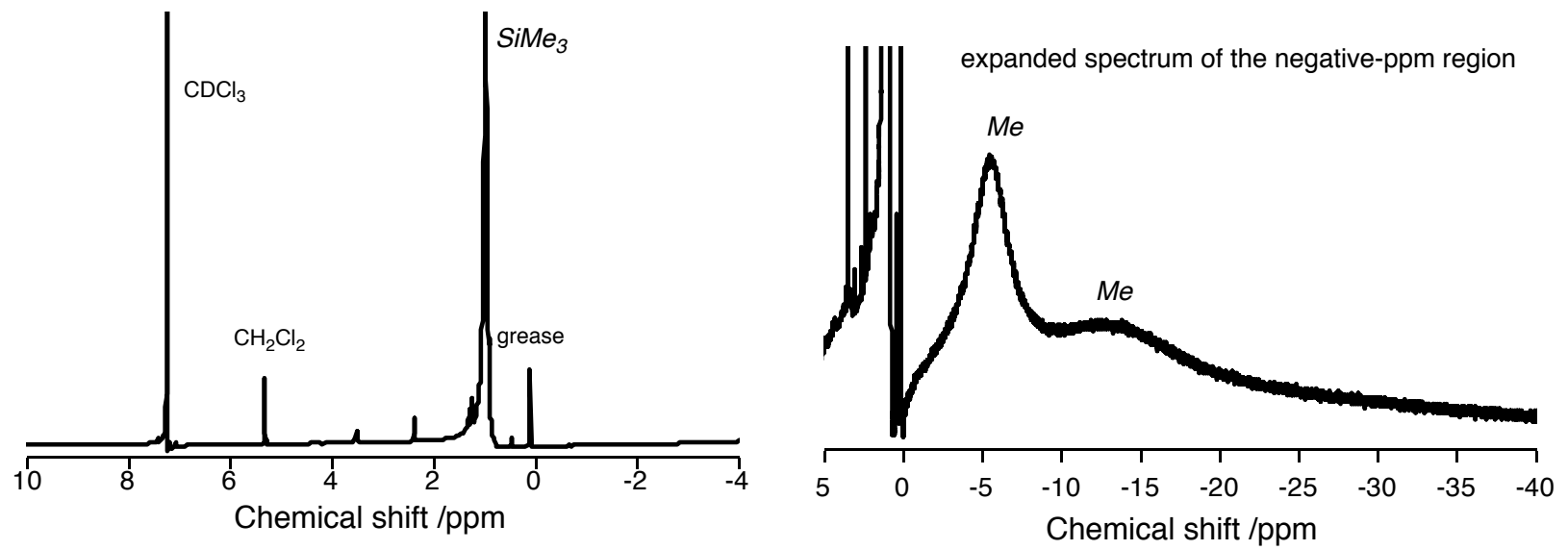

Figure S1 ${ }^{1} \mathrm{H}$ NMR spectrum of $\left(\mathrm{C}_{5} \mathrm{Me}_{4} \mathrm{SiMe}_{3}\right) \mathrm{MoCl}_{4}$ (1a) in $\mathrm{CDCl}_{3}$.
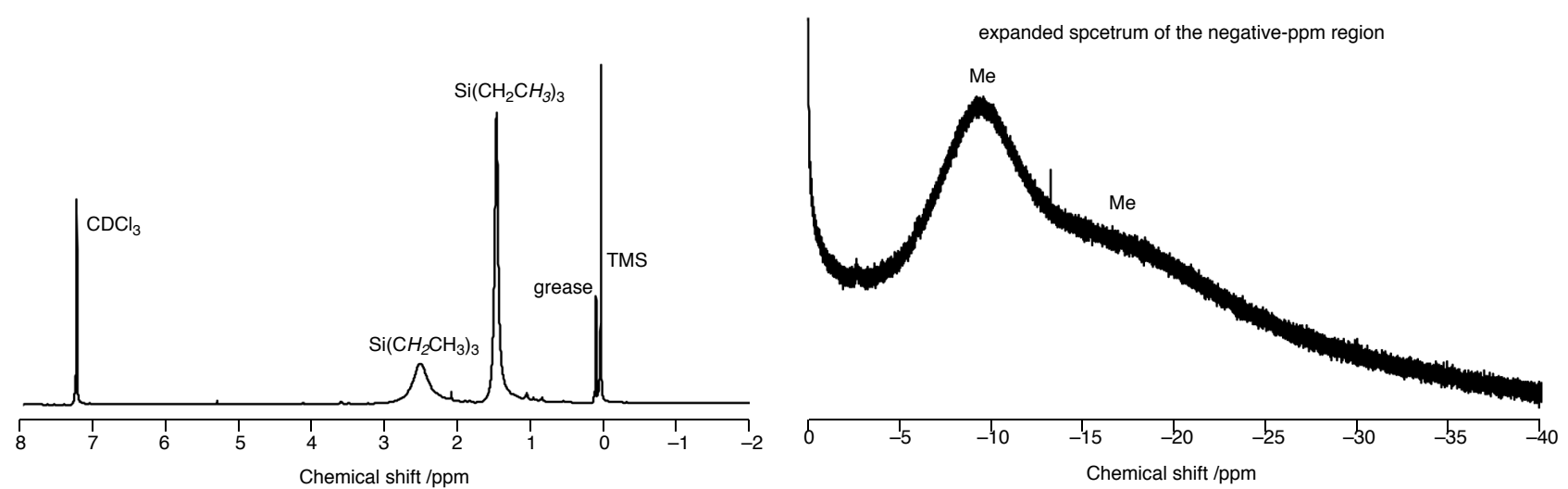

Figure S2 ${ }^{1} \mathrm{H} \mathrm{NMR}$ spectrum of $\left(\mathrm{C}_{5} \mathrm{Me}_{4} \mathrm{SiEt}_{3}\right) \mathrm{MoCl}_{4}(\mathbf{1 b})$ in $\mathrm{CDCl}_{3}$. 

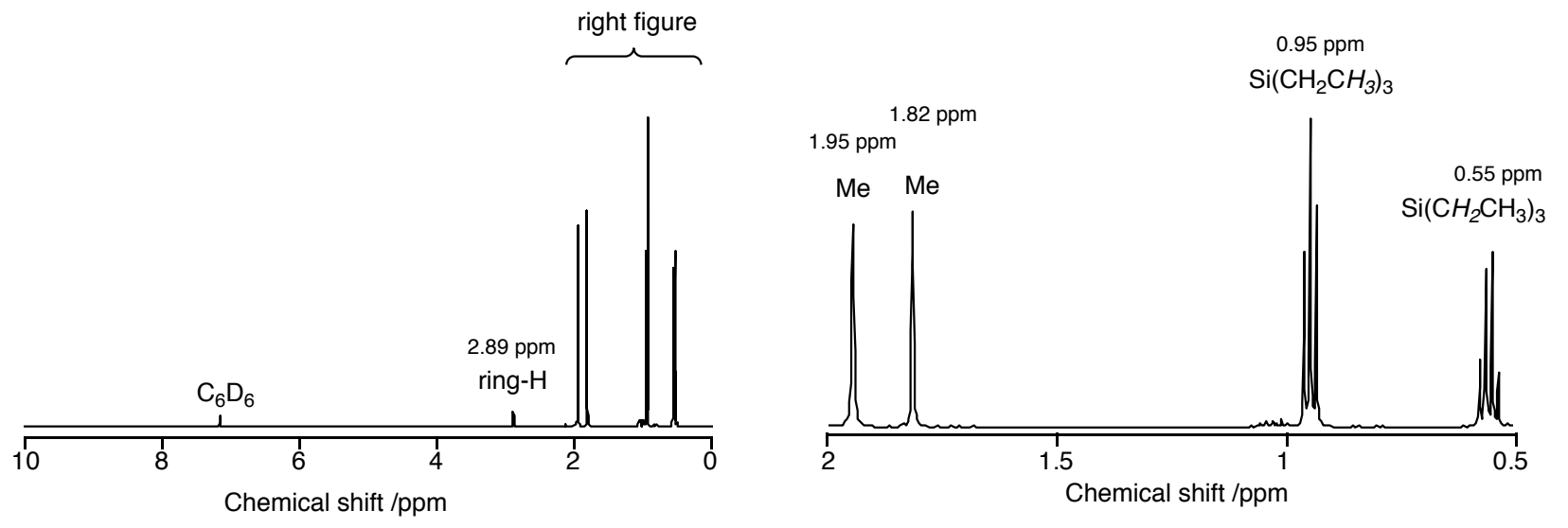

Figure S3 ${ }^{1} \mathrm{H}$ NMR spectrum of $\mathrm{C}_{5} \mathrm{Me}_{4} \mathrm{SiEt}_{3} \mathrm{H}$ in $\mathrm{C}_{6} \mathrm{D}_{6}$.

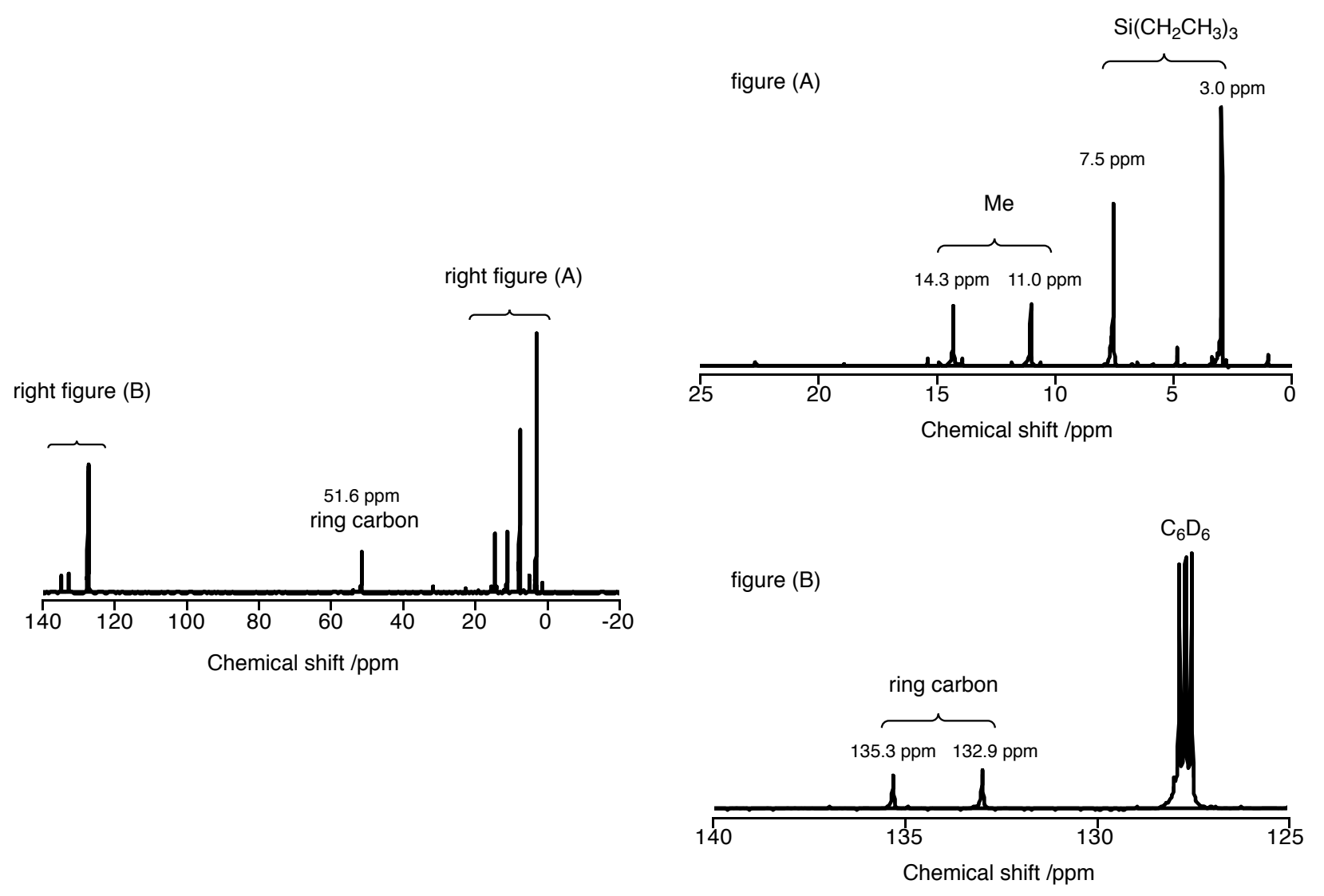

Figure S4 ${ }^{13} \mathrm{C}\left\{{ }^{1} \mathrm{H}\right\}$ NMR spectrum of $\mathrm{C}_{5} \mathrm{Me}_{4} \mathrm{SiEt}_{3} \mathrm{H}$ in $\mathrm{C}_{6} \mathrm{D}_{6}$. 


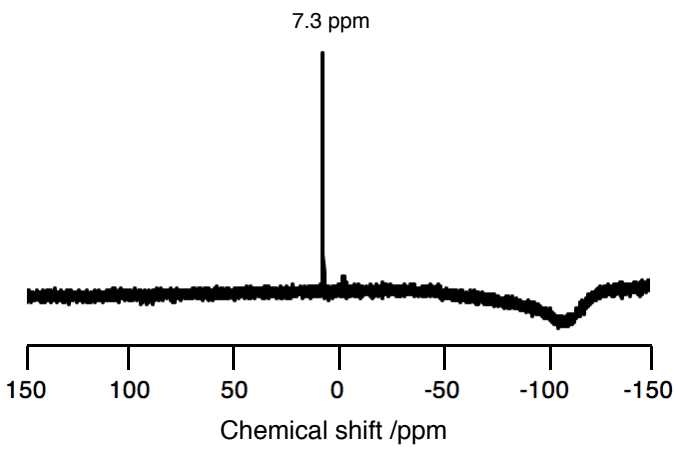

Figure S5 ${ }^{29} \mathrm{Si}\left\{{ }^{1} \mathrm{H}\right\}$ NMR spectrum of $\mathrm{C}_{5} \mathrm{Me}_{4} \mathrm{SiEt}_{3} \mathrm{H}$ in $\mathrm{C}_{6} \mathrm{D}_{6}$.

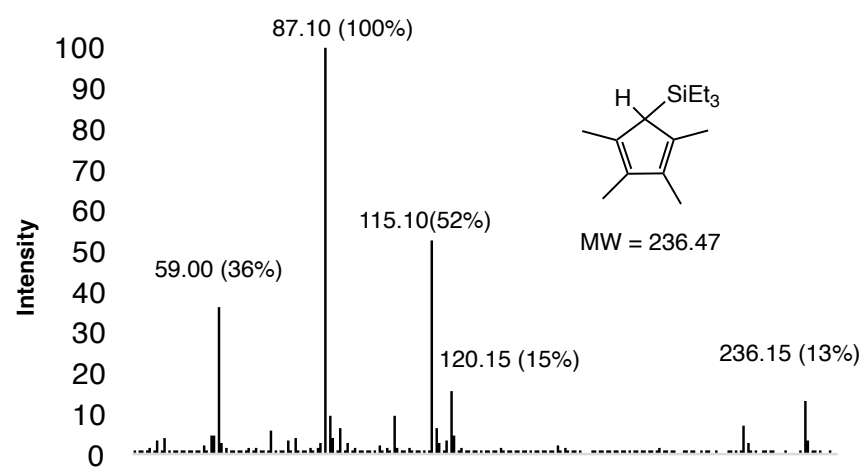

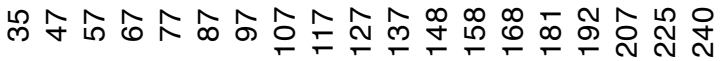

$m / 2$

Figure S6 GC-MS chart of $\mathrm{C}_{5} \mathrm{Me}_{4} \mathrm{SiEt}_{3} \mathrm{H}$. 

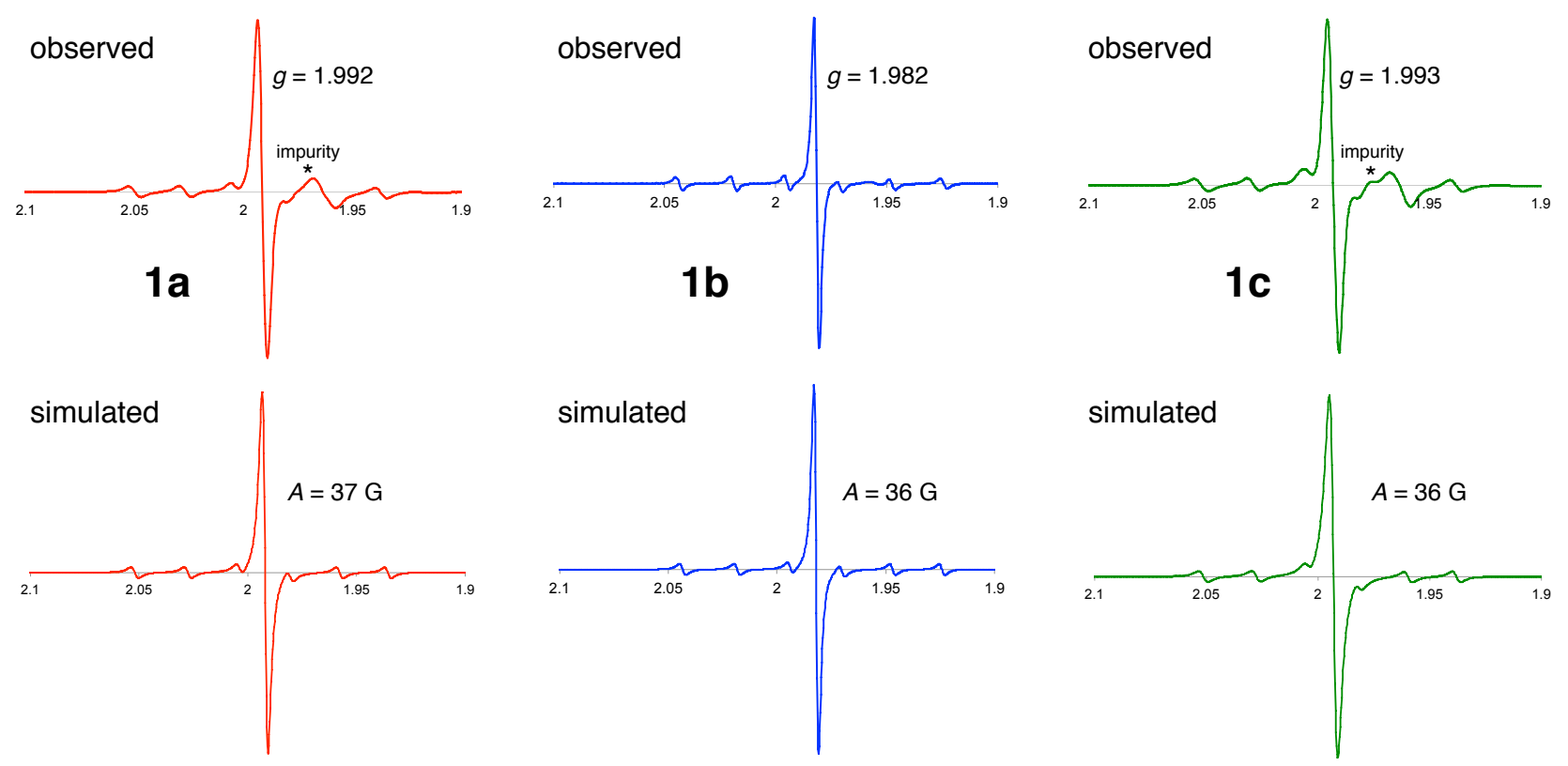

Figure S7 X-band ESR spectra of $\left(\mathrm{C}_{5} \mathrm{Me}_{4} \mathrm{SiMe}_{3}\right) \mathrm{MoCl}_{4}(\mathbf{1 a}),\left(\mathrm{C}_{5} \mathrm{Me}_{4} \mathrm{SiEt}_{3}\right) \mathrm{MoCl}_{4}(\mathbf{1 b})$, and $\left(\mathrm{C}_{5} \mathrm{Me}_{4} \mathrm{H}\right) \mathrm{MoCl}_{4}(\mathbf{1 c})$ in $\mathrm{CH}_{2} \mathrm{Cl}_{2}$ at room temperature (Top) and their simulated spectra (Bottom). Measurement conditions: frequency $9.50 \mathrm{GHz}(\mathbf{1 a}, \mathbf{1 c})$ or $8.983 \mathrm{GHz}(\mathbf{1 b})$, microwave power 0.5 $\mathrm{mW}$. Coupling to ${ }^{97} \mathrm{Mo} /{ }^{95} \mathrm{Mo}(I=5 / 2)$ was analyzed as $37 \mathrm{G}(\mathbf{1 a}), 36 \mathrm{G}(\mathbf{1 b})$, and $36 \mathrm{G}(\mathbf{1 c})$ based on the simulation. Relative intensity of $3 \%$ was applied for the simulated isotope couplings.

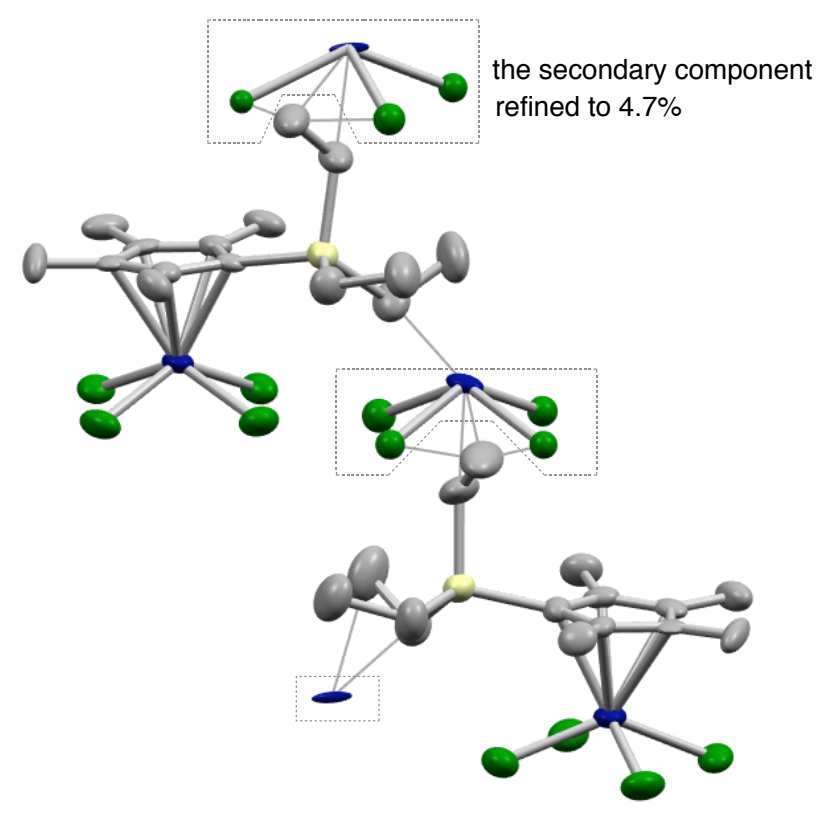

Figure S8 Consideration of the residual electron densities in the crystal analysis of $\mathbf{1 b}$. Crystals of this material grew as starburst clusters of very fine needles. By cutting pieces from longer crystals, we were able to obtain two low quality but usable data sets. One crystal was very small and 
although we used long exposure times the data was very weak. The second crystal was larger and yielded stronger data, but residual peaks of nearly 5 e/A remained after all of the molecule was included in the model. These peaks had the geometry of two $\mathrm{MoCl}_{4}$ groups, which were separated from the main molecules by $.5+x, .5-y, z$. Refinement of the occupancy of these peaks yielded a contribution of $4.7 \%$ of the main crystal. Thus the data for the second crystal, which we report here, is contaminated by a small secondary crystal. The std dev for the bond lengths from both data sets were mostly the same and one digit smaller for the second crystal in a few cases. Most of the bond lengths from the two data sets agreed within one std dev and all within three std dev. Thus any distortion caused by the secondary crystal is less than experimental error. This figure includes the $2 \mathrm{Mo}$ and $7 \mathrm{Cl}$ atoms from the secondary crystal.
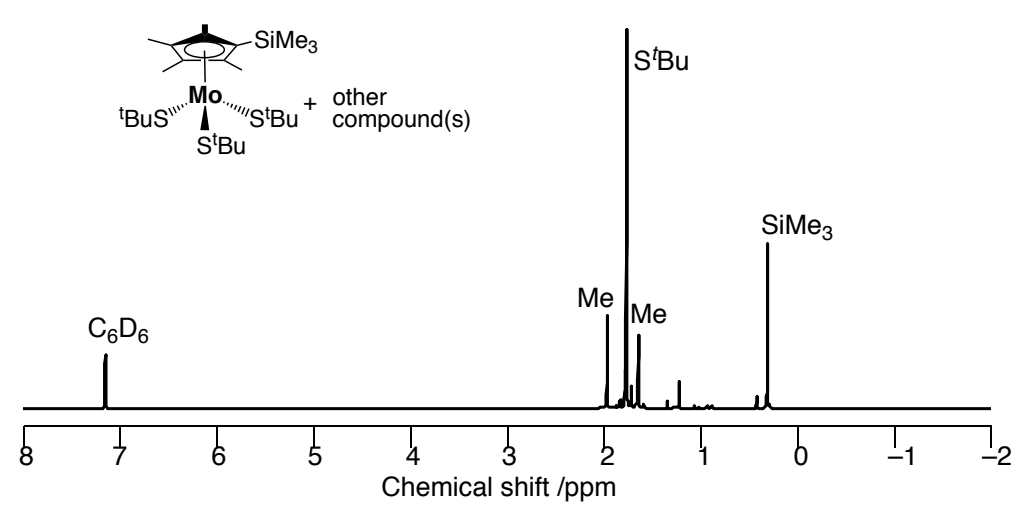

Figure S9 ${ }^{1} \mathrm{H}$ NMR spectrum of the hexane extract of $\mathbf{1 a}+\mathrm{LiS}^{t} \mathrm{Bu}$ (4 eq.). Some minor signals of byproducts appear. 


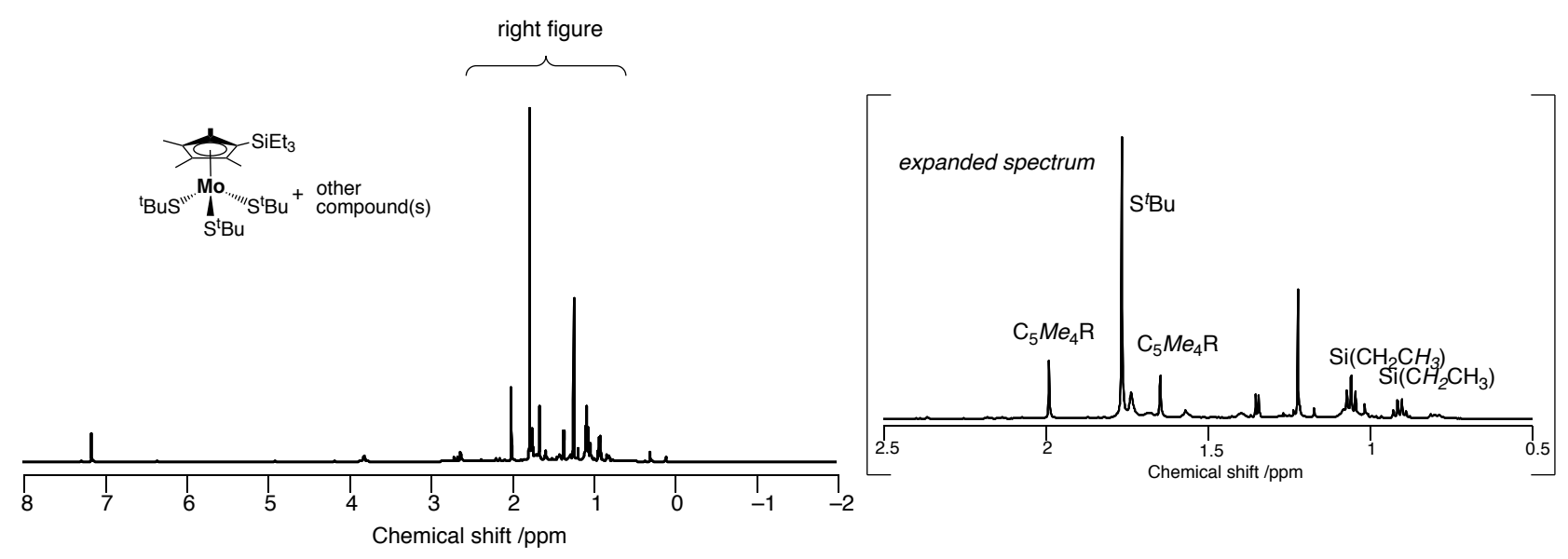

Figure S10 ${ }^{1} \mathrm{H}$ NMR spectrum of the hexane extract of $\mathbf{1 b}+\mathrm{LiS}^{t} \mathrm{Bu}$ (4 eq.). Some minor signals of byproducts appear.

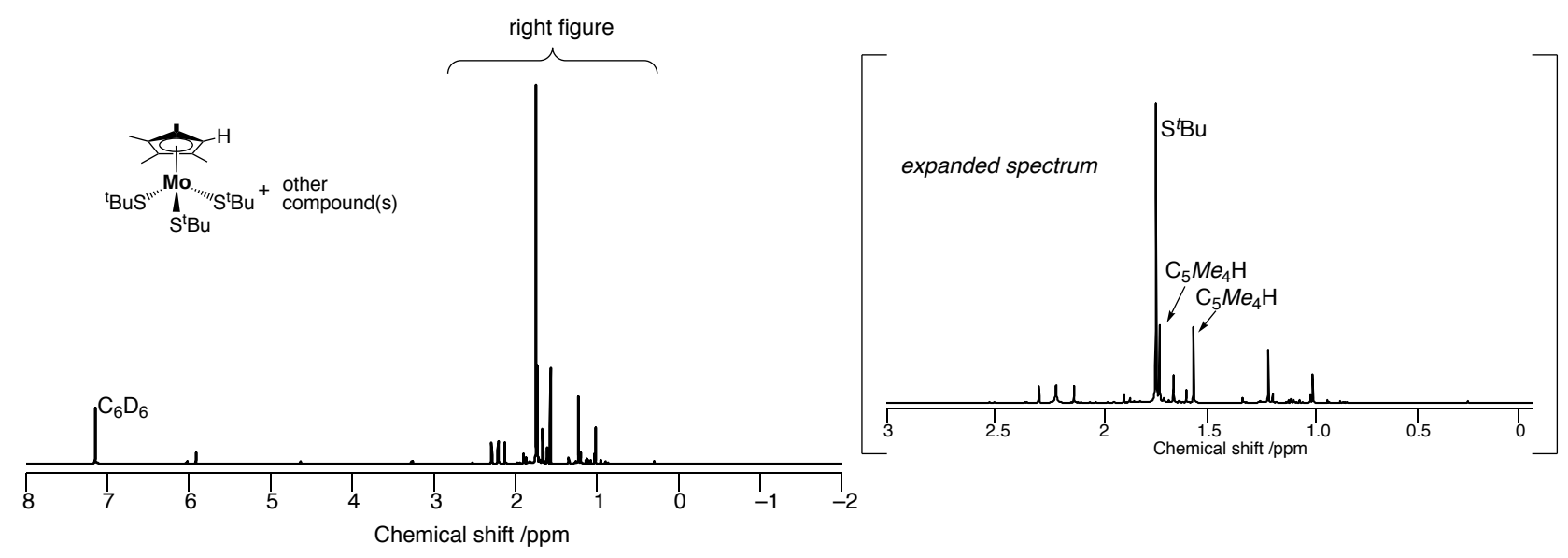

Figure S11 ${ }^{1} \mathrm{H}$ NMR spectrum of the hexane extract of $\mathbf{1 c}+\mathrm{LiS}^{t} \mathrm{Bu}(4$ eq.). Some minor signals of byproducts appear. 


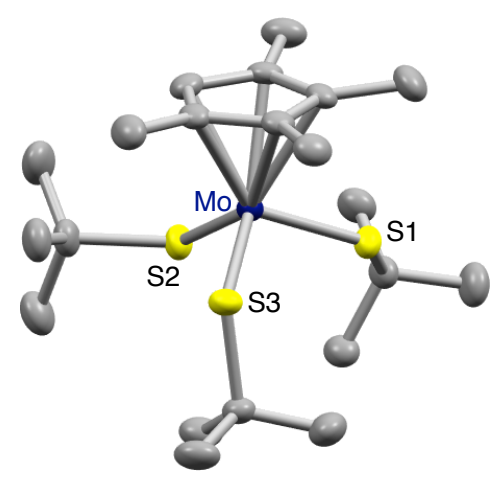

Figure S12 Molecular structure of $\left(\mathrm{C}_{5} \mathrm{Me}_{4} \mathrm{H}\right) \mathrm{Mo}\left(\mathrm{S}^{t} \mathrm{Bu}\right)_{3}$ (2c) with atomic displacement parameters set at 50\% probability. Hydrogen atoms are omitted for clarity. Crystals were manually picked up from the reaction mixture of $1 \mathbf{c}+\operatorname{LiS}^{t} \mathrm{Bu}(4$ eq.). Note that four independent molecules appeared in an asymmetric unit, and one of these is shown in this figure. Selected bond distances ( $)$ : Mo-S1 2.2733(6), Mo-S2 2.2780(5), Mo-S3 2.3279(5).

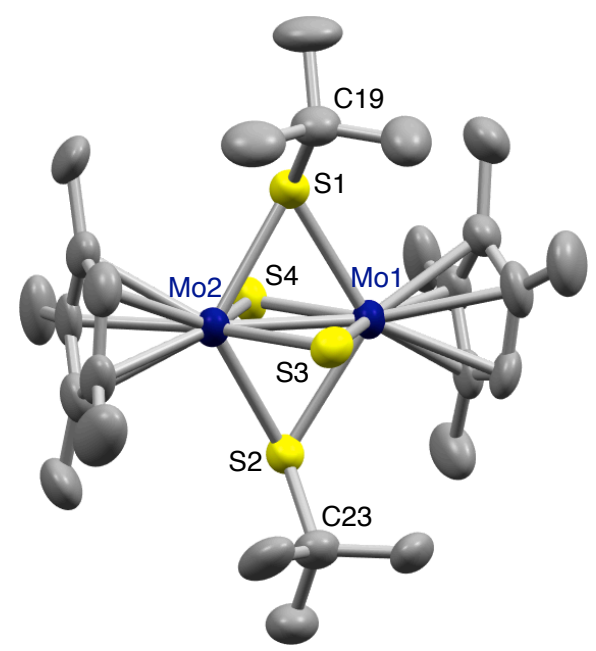

Figure S13 Molecular structure of one of the byproducts $\left(\mathrm{C}_{5} \mathrm{Me}_{4} \mathrm{H}\right)_{2} \mathrm{Mo}_{2}(\mu-\mathrm{S})_{2}\left(\mu-\mathrm{S}{ }^{t} \mathrm{Bu}\right)_{2}(\mathbf{A})$ with atomic displacement parameters set at 50\% probability. Hydrogen atoms are omitted for clarity. Crystals were manually picked up from the reaction mixture of $1 \mathrm{c}+\mathrm{LiS}^{t} \mathrm{Bu}$ (4 eq.). Selected bond distances ( $\AA$ ): Mo1-Mo2 2.5945(15), Mo1-S1 2.491(2), Mo1-S2 2.488(3), Mo1-S3 2.368(2), Mo1-S4 2.347(3), Mo2-S1 2.483(3), Mo2-S2 2.485(2), Mo2-S3 2.370(3), Mo2-S4 2.343(2), S1-C19 1.896(7), S2-C23 1.896(11). 


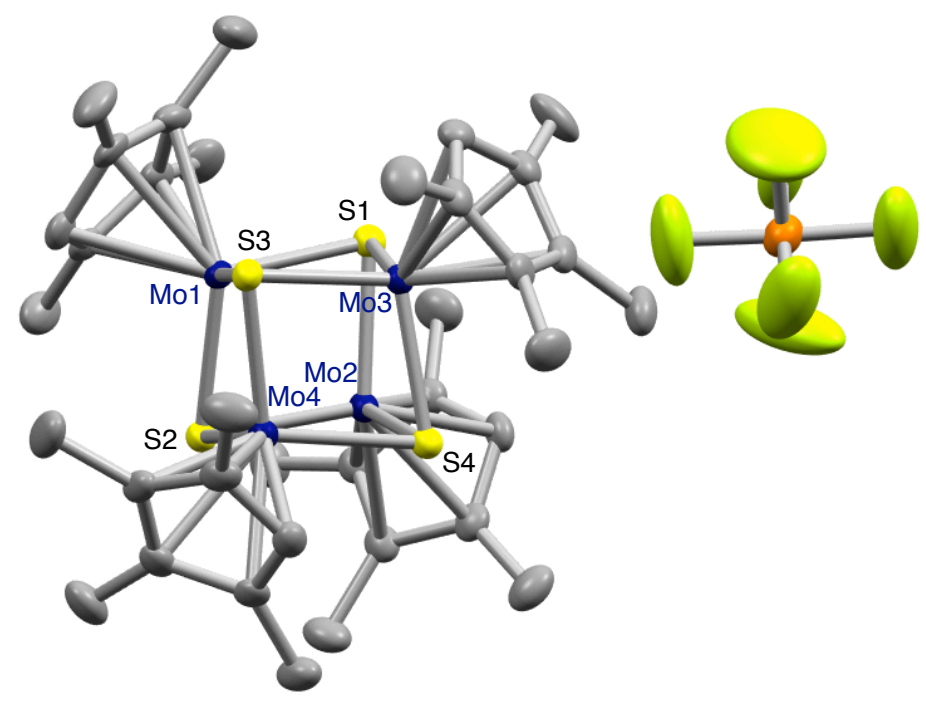

Figure S14 Molecular structure of one of the byproducts $\left[\left(\mathrm{C}_{5} \mathrm{Me}_{4} \mathrm{H}\right)_{4} \mathrm{Mo}_{4} \mathrm{~S}_{4}\right]\left[\mathrm{PF}_{6}\right](\mathbf{B})$, crystals of which were manually picked up from the reaction mixture of $\mathbf{1 c}+\mathrm{Li}_{2} \mathrm{~S}_{2}+\mathrm{KC}_{8}$ (3:2:7 ratio). Thermal ellipsoids are set at 50\% probability, and hydrogen atoms are omitted for clarity. Selected bond distances ( $\AA$ ): Mo1-Mo2 2.8931(5), Mo1-Mo3 2.8854(5), Mo1-Mo4 2.8577(6), Mo2-Mo3 2.8959(6), Mo2-Mo4 2.9035(5), Mo3-Mo4 2.9138(5), Mo1-S1 2.3373(10), Mo1-S2 2.3534(11), Mo1-S3 2.3429(11), Mo2-S1 2.3331(10), Mo2-S2 2.3497(10), Mo2-S4 2.3446(10). 

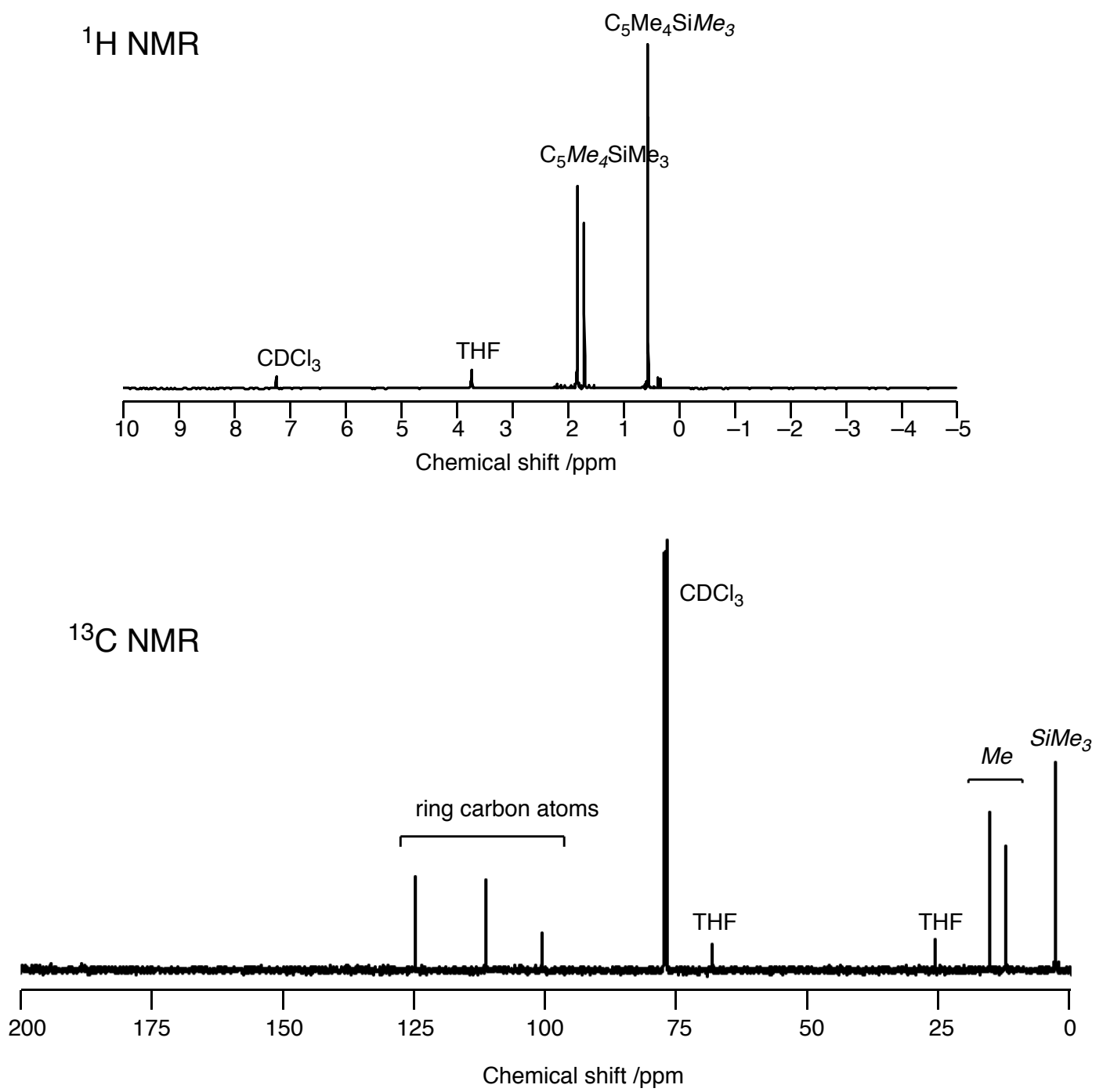

Figure S15 $\quad{ }^{1} \mathrm{H}$ and ${ }^{13} \mathrm{C}\left\{{ }^{1} \mathrm{H}\right\}$ NMR spectra of $\left[\left(\mathrm{C}_{5} \mathrm{Me}_{4} \mathrm{SiMe}_{3}\right)_{3} \mathrm{Mo}_{3} \mathrm{~S}_{4}\right]\left[\mathrm{PF}_{6}\right](\mathbf{3 a})$ in $\mathrm{CDCl}_{3}$. 

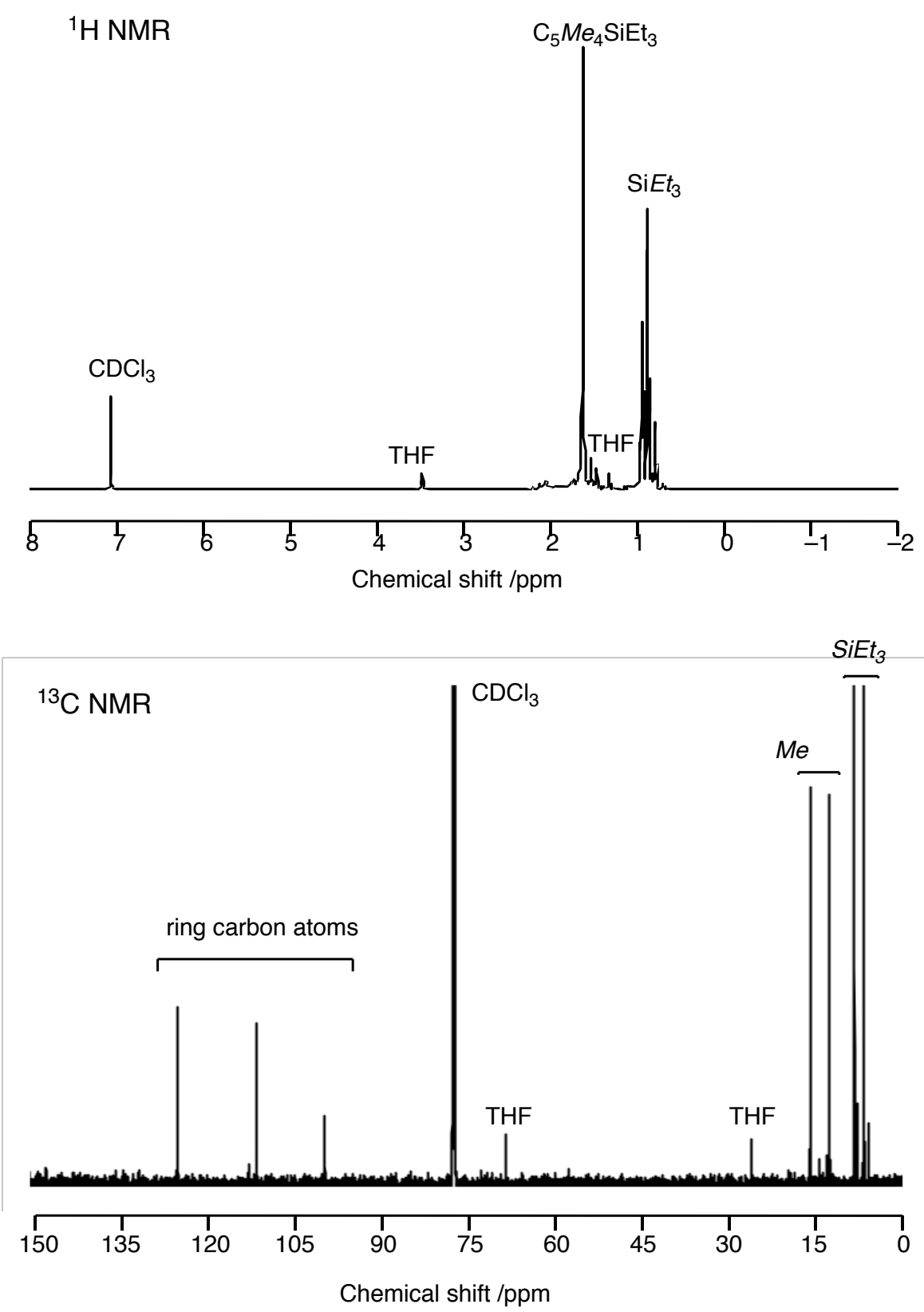

Figure S16 ${ }^{1} \mathrm{H}$ and ${ }^{13} \mathrm{C}\left\{{ }^{1} \mathrm{H}\right\}$ NMR spectra of $\left[\left(\mathrm{C}_{5} \mathrm{Me}_{4} \mathrm{SiEt}_{3}\right)_{3} \mathrm{Mo}_{3} \mathrm{~S}_{4}\right]\left[\mathrm{PF}_{6}\right](\mathbf{3 b})$ in $\mathrm{CDCl}_{3}$. 

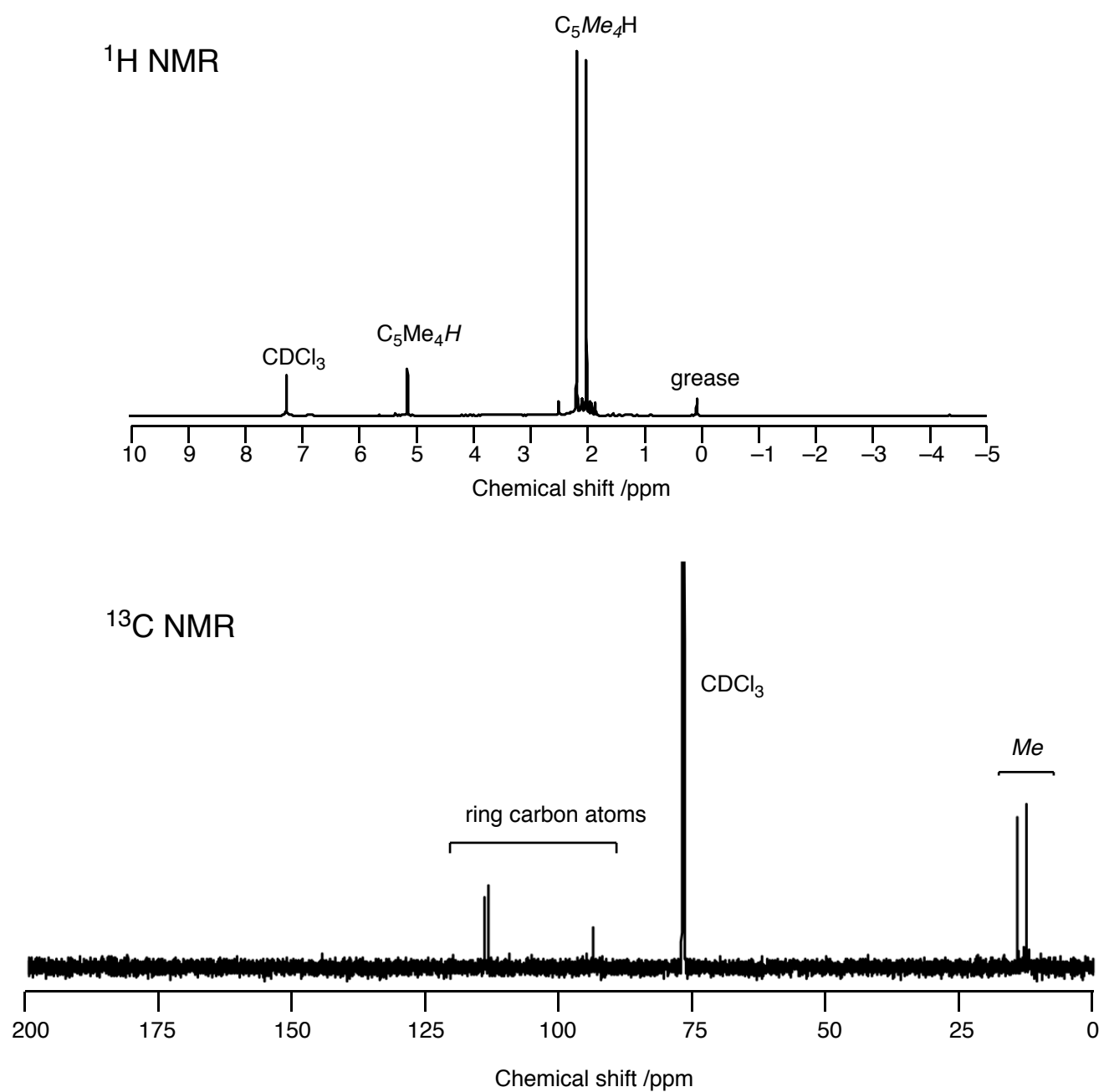

Figure S17 ${ }^{1} \mathrm{H}$ and ${ }^{13} \mathrm{C}\left\{{ }^{1} \mathrm{H}\right\}$ NMR spectra of $\left[\left(\mathrm{C}_{5} \mathrm{Me}_{4} \mathrm{H}\right)_{3} \mathrm{Mo}_{3} \mathrm{~S}_{4}\right]\left[\mathrm{PF}_{6}\right](\mathbf{3 c})$ in $\mathrm{CDCl}_{3}$. 


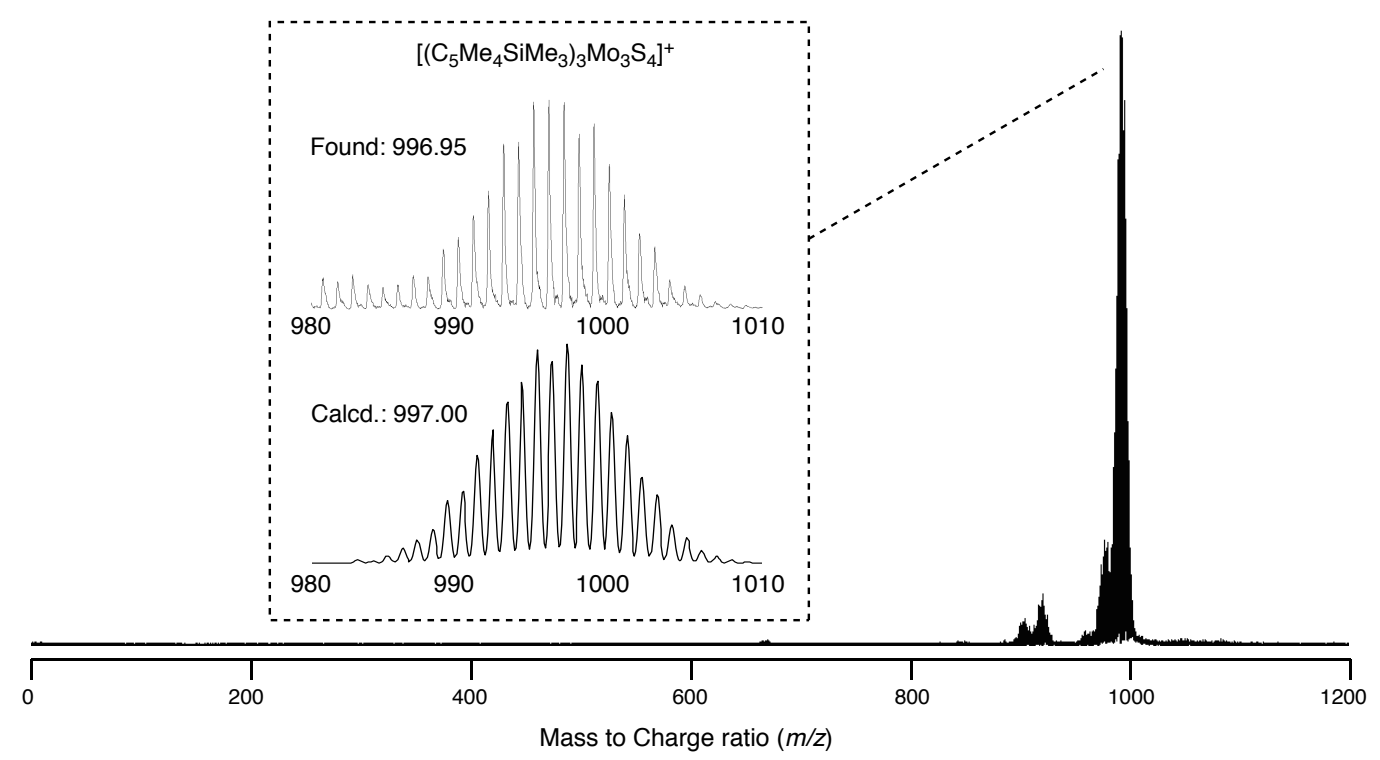

Figure S18 ESI-MS spectrum of 3a in THF.

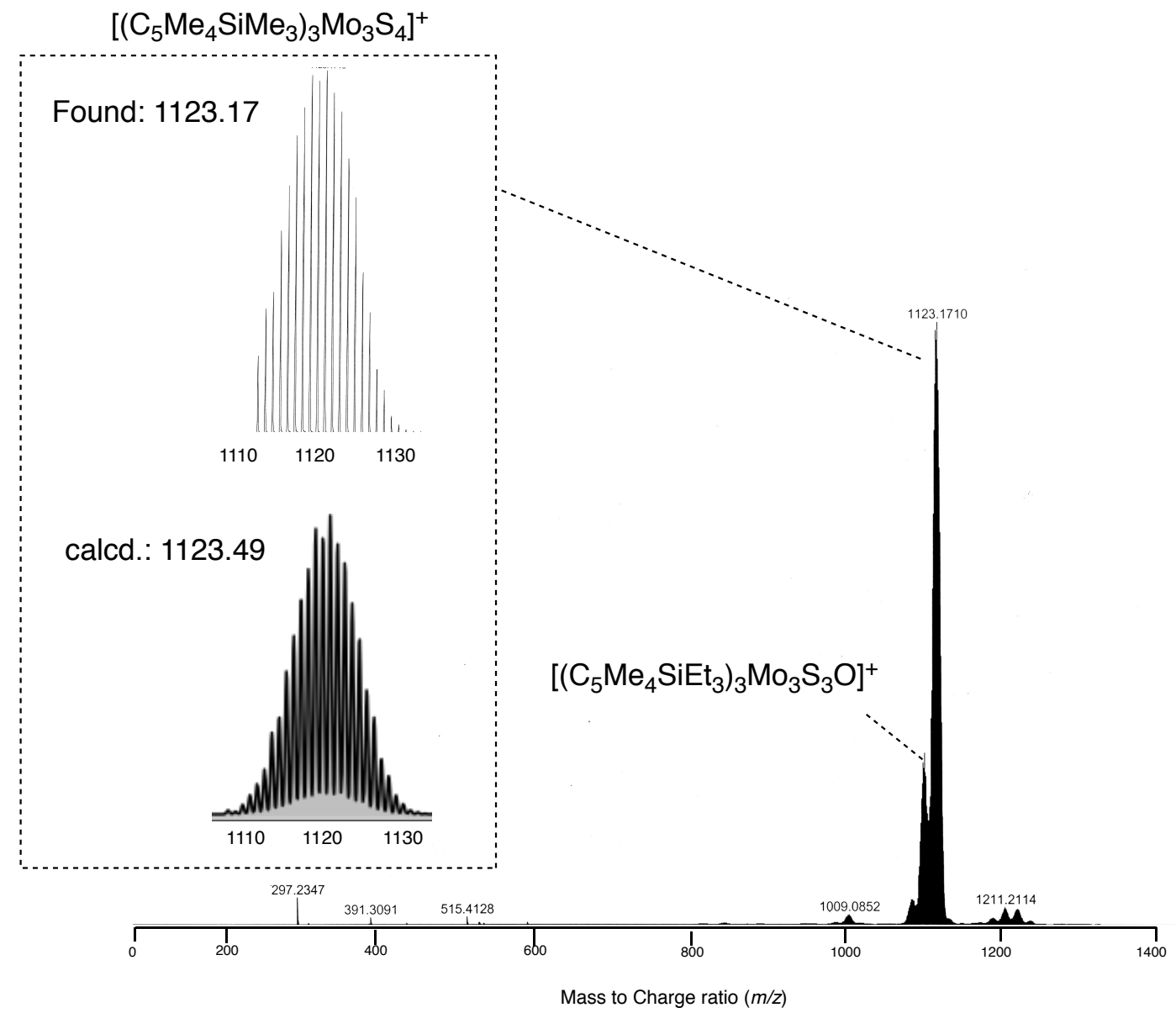

Figure S19 ESI-MS spectrum of $\mathbf{3 b}$ in THF. 


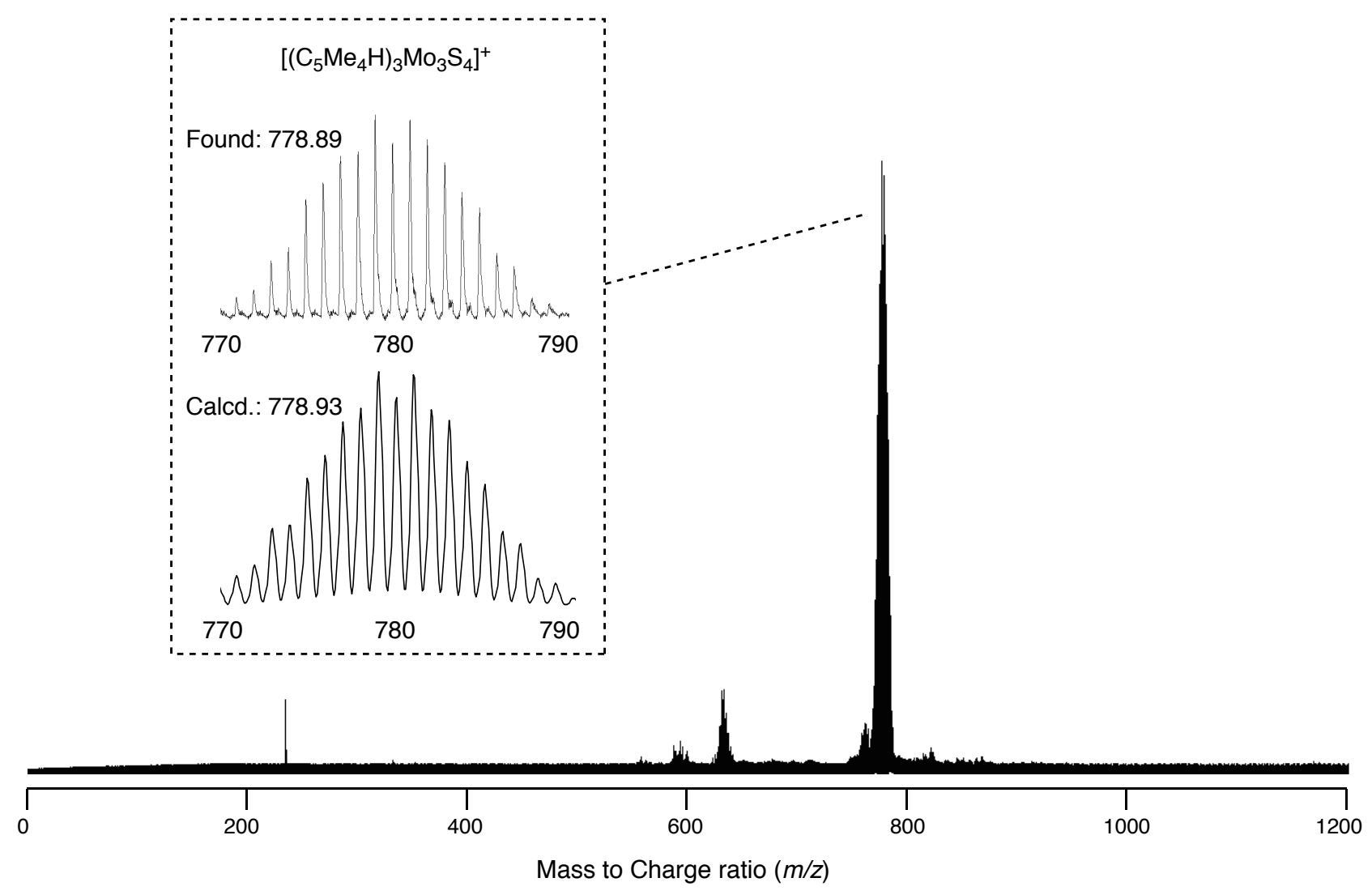

Figure S20 ESI-MS spectrum of $\mathbf{3 c}$ in THF. 


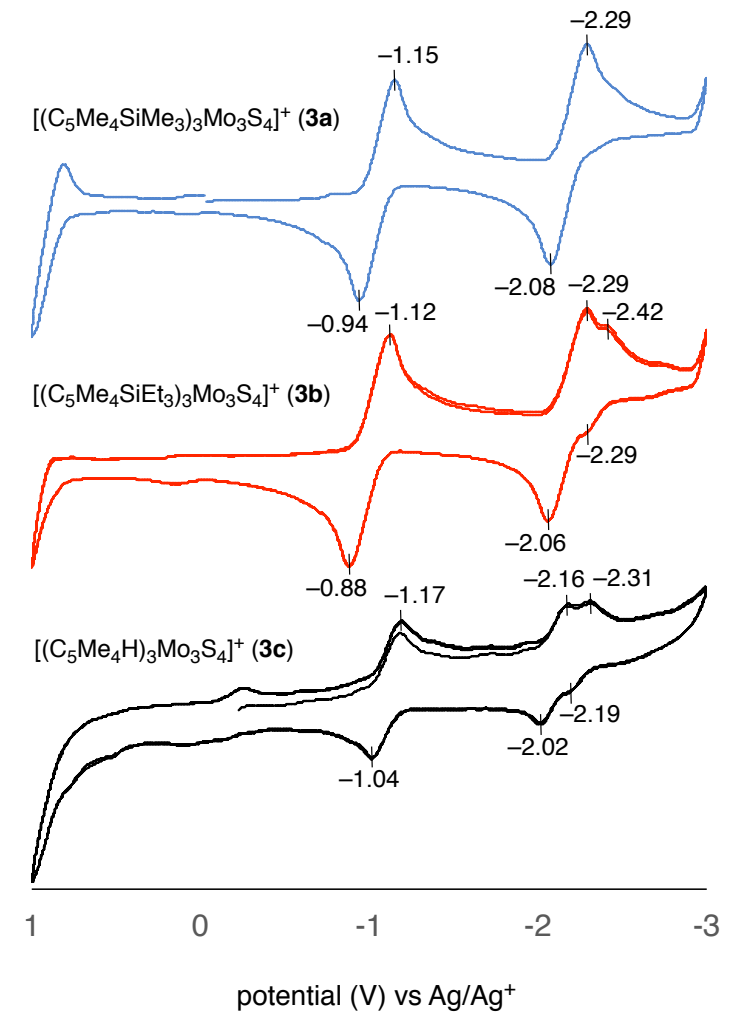

Figure S21 Cyclic voltammograms of 3a-3c in THF at room temperature. Measurement conditions: scan rate $=0.1 \mathrm{~V} / \mathrm{s}$; concentration $=4.0 \mathrm{mM}$; concentration $\left(\left[{ }^{n} \mathrm{Bu}_{4} \mathrm{~N}\right]\left[\mathrm{PF}_{6}\right]\right)=0.2 \mathrm{M}$; working electrode $=$ glassy carbon; reference electrode $=\mathrm{Ag} / \mathrm{AgNO}_{3}$; counter electrode $=\mathrm{Pt}$. 


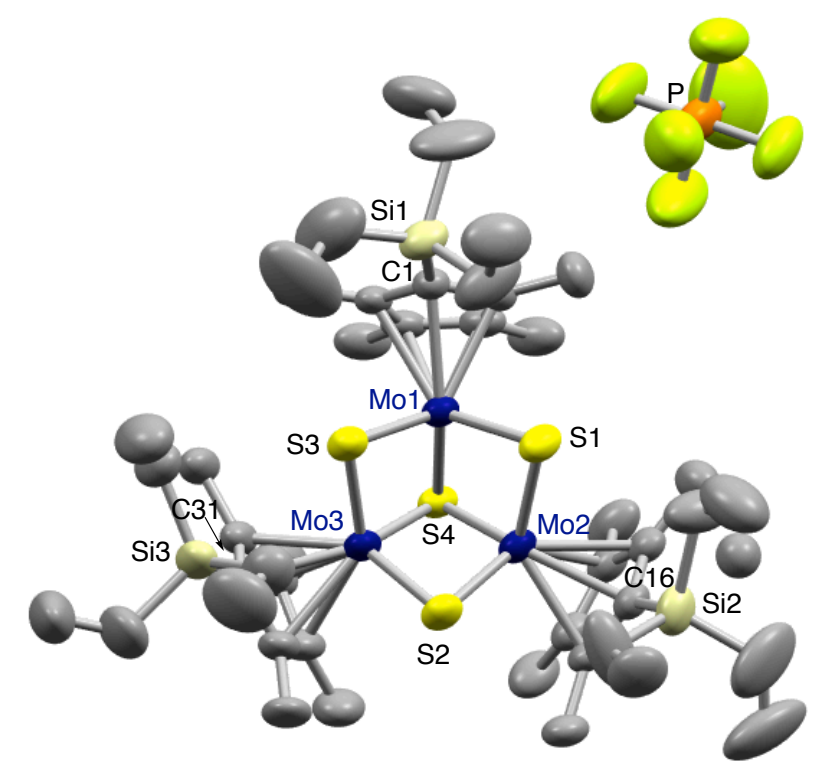

Figure S22 Molecular structure of $\left[\left(\mathrm{C}_{5} \mathrm{Me}_{4} \mathrm{SiEt}_{3}\right)_{3} \mathrm{Mo}_{3} \mathrm{~S}_{4}\right]\left[\mathrm{PF}_{6}\right](\mathbf{3 b})$ with thermal ellipsoids set at 50\% probability. Selected bond distances (Å): Mo1-Mo2 2.8076(5), Mo1-Mo3 2.8098(5), Mo2-Mo3 2.8103(5), Mo1-S1 2.2807(10), Mo1-S3 2.2566(11), Mo1-S4 2.3243(9), Mo2-S1 2.2970(10), Mo2-S2 2.2837(11), Mo2-S4 2.3195(9), Mo3-S2 2.2892(10), Mo3-S3 2.2931(10), Mo3-S4 2.3192(10), Si1-C1 1.898(4), Si2-C16 1.889(4), Si3-C31 1.898(5). 


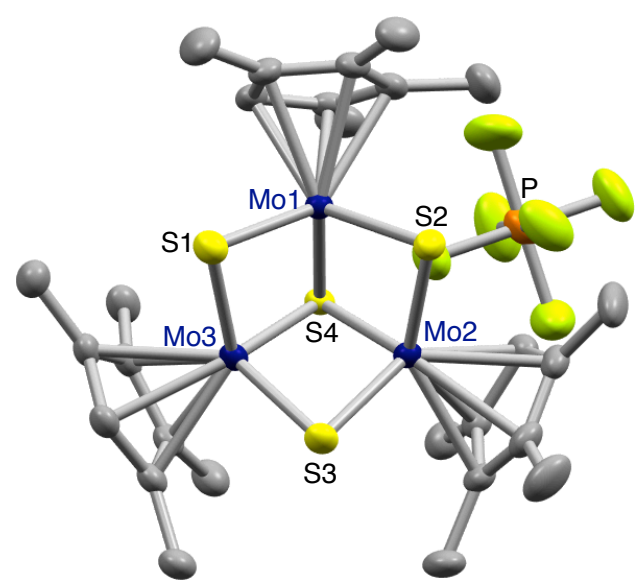

Figure S23 Molecular structure of $\left[\left(\mathrm{C}_{5} \mathrm{Me}_{4} \mathrm{H}\right)_{3} \mathrm{Mo}_{3} \mathrm{~S}_{4}\right]\left[\mathrm{PF}_{6}\right]$ (3c) with thermal ellipsoids set at 50\% probability. Selected bond distances (Å): Mo1-Mo2 2.7945(4), Mo1-Mo3 2.7964(4), Mo2-Mo3 2.8098(4), Mo1-S1 2.2831(8), Mo1-S2 2.2912(7), Mo1-S4 2.3179(7), Mo2-S2 2.2959(7), Mo2-S3 2.3089(7), Mo2-S4 2.3159(6), Mo3-S1 2.2945(7), Mo3-S3 2.2972(7), Mo3-S4 2.3181(6).

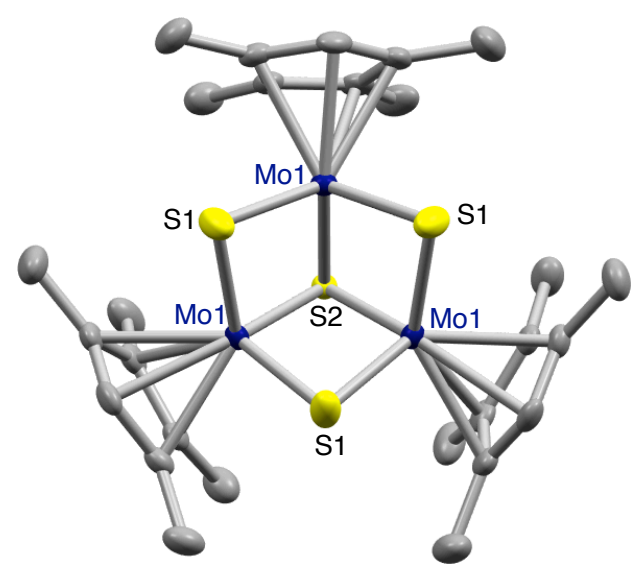

Figure S24 Molecular structure of $\left(\mathrm{C}_{5} \mathrm{Me}_{4} \mathrm{H}\right)_{3} \mathrm{Mo}_{3} \mathrm{~S}_{4}(\mathbf{4 c})$ with thermal ellipsoids set at $50 \%$ probability. Selected bond distances (Å): Mo1-Mo1* 2.8364(6), Mo1-S1 2.3058(8), Mo1-S1* 2.3109(8), Mo1-S2 2.3361(7). 


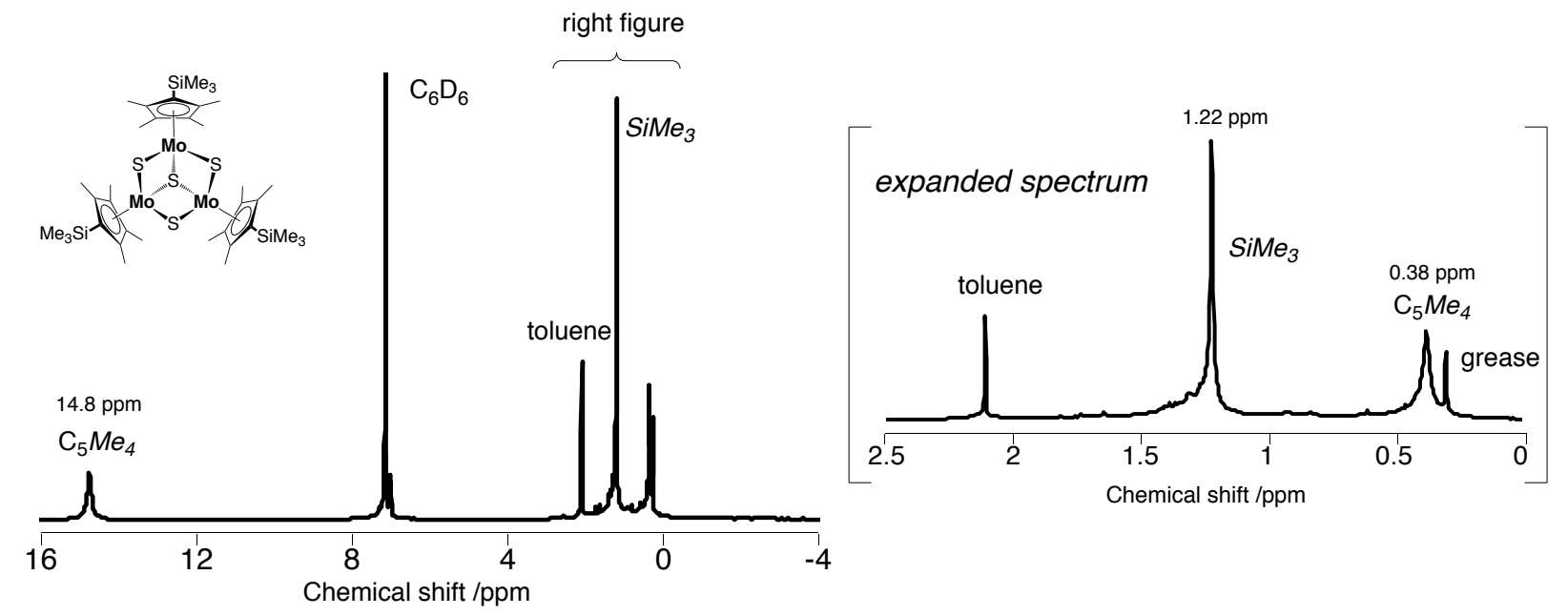

Figure S25 ${ }^{1} \mathrm{H}$ NMR spectrum of $\left(\mathrm{C}_{5} \mathrm{Me}_{4} \mathrm{SiMe}_{3}\right)_{3} \mathrm{Mo}_{3} \mathrm{~S}_{4}(\mathbf{4 a})$ in $\mathrm{C}_{6} \mathrm{D}_{6}$.

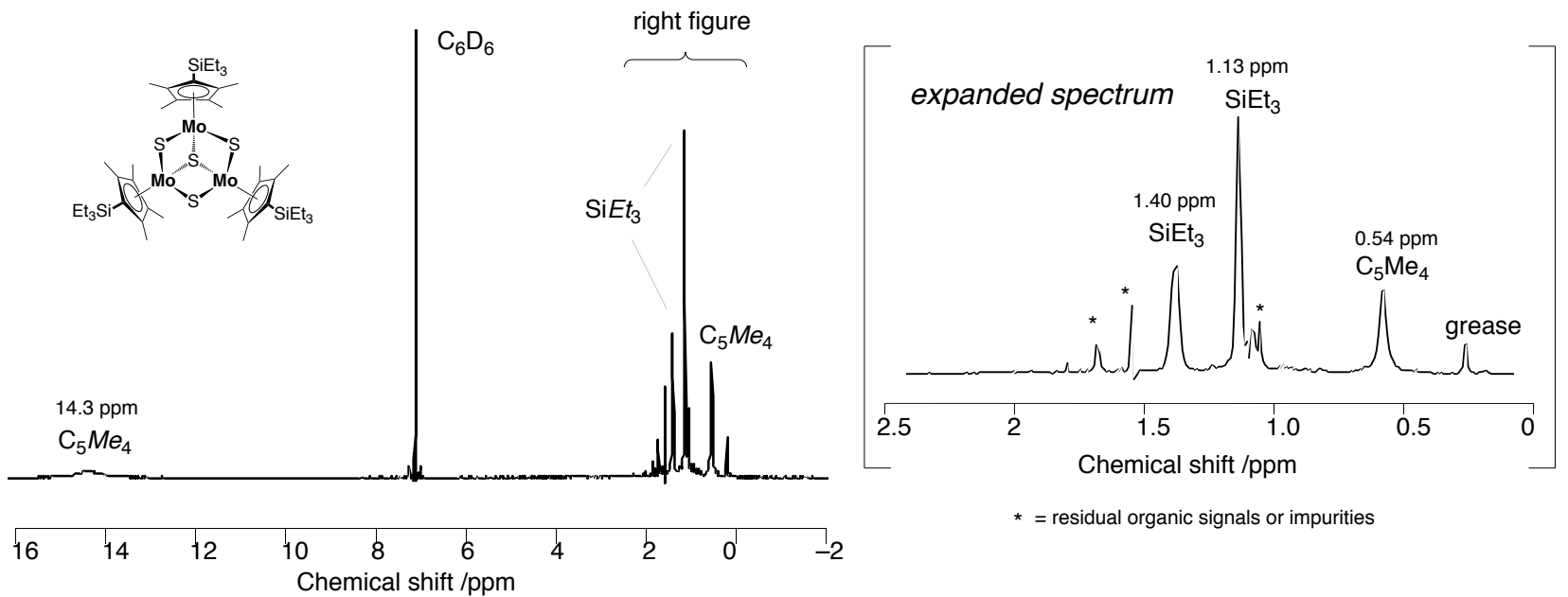

Figure S26 ${ }^{1} \mathrm{H}$ NMR spectrum of $\left(\mathrm{C}_{5} \mathrm{Me}_{4} \mathrm{SiEt}_{3}\right)_{3} \mathrm{Mo}_{3} \mathrm{~S}_{4}(\mathbf{4 b})$ in $\mathrm{C}_{6} \mathrm{D}_{6}$. 


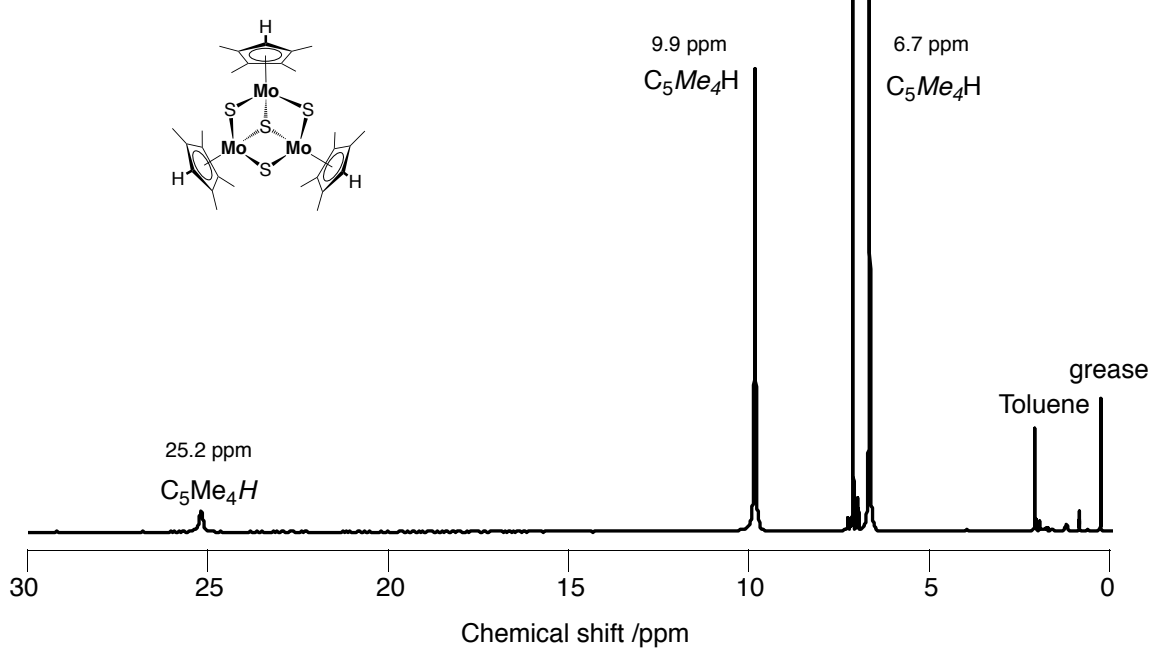

Figure S27 ${ }^{1} \mathrm{H}$ NMR spectrum of $\left(\mathrm{C}_{5} \mathrm{Me}_{4} \mathrm{H}\right)_{3} \mathrm{Mo}_{3} \mathrm{~S}_{4}(\mathbf{4 c})$ in $\mathrm{C}_{6} \mathrm{D}_{6}$.

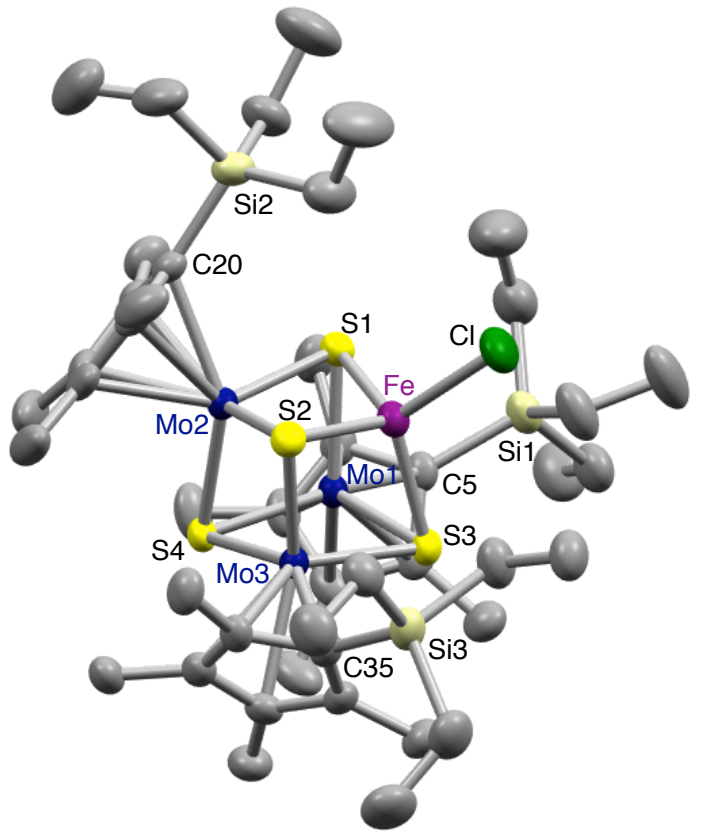

Figure S28 Molecular structure of $\left(\mathrm{C}_{5} \mathrm{Me}_{4} \mathrm{SiEt}_{3}\right)_{3} \mathrm{Mo}_{3} \mathrm{~S}_{4} \mathrm{FeCl}(\mathbf{5 b})$ with thermal ellipsoids set at $50 \%$ probability. Note that two independent molecules appeared in an asymmetric unit, and one of these is shown in this figure. Selected bond distances ( $\AA$ ): Mo1-Mo2 2.8714(6), Mo1-Mo3 2.8742(8), Mo2-Mo3 2.8799(7), Mo1-Fe 2.7802(8), Mo1-S1 2.3379(10), Mo1-S3 2.3457(10), Mo1-S4 2.3348(10), Mo2-Fe 2.7759(8), Mo2-S1 2.3391(11), Mo2-S2 2.3380(10), Mo2-S4 2.3405(10), Mo3-Fe 2.7874(8), Mo3-S2 2.3372(10), Mo3-S3 2.3455(10), Mo3-S4 2.3366(9), Fe-Cl 2.2086(12), Fe-S1 2.2433(11), Fe-S2 2.2451(11), Fe-S3 2.2460(11), Si1-C5 1.889(4), Si2-C20 1.892(4), Si3-C35 1.891(4). 


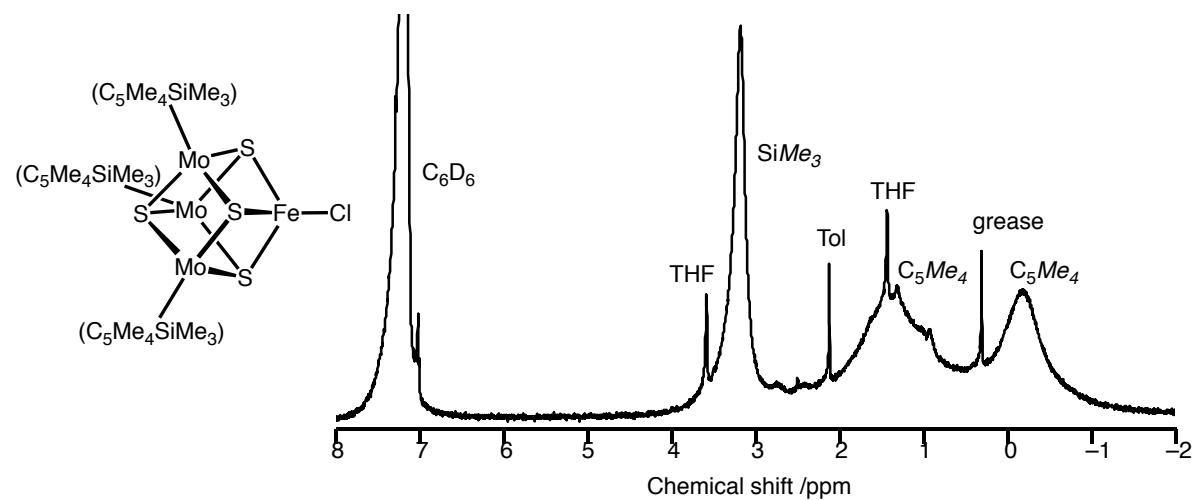

Figure S29 ${ }^{1} \mathrm{H}$ NMR spectrum of $\left(\mathrm{C}_{5} \mathrm{Me}_{4} \mathrm{SiMe}_{3}\right)_{3} \mathrm{Mo}_{3} \mathrm{~S}_{4} \mathrm{FeCl}(\mathbf{5 a})$ in $\mathrm{C}_{6} \mathrm{D}_{6}$.

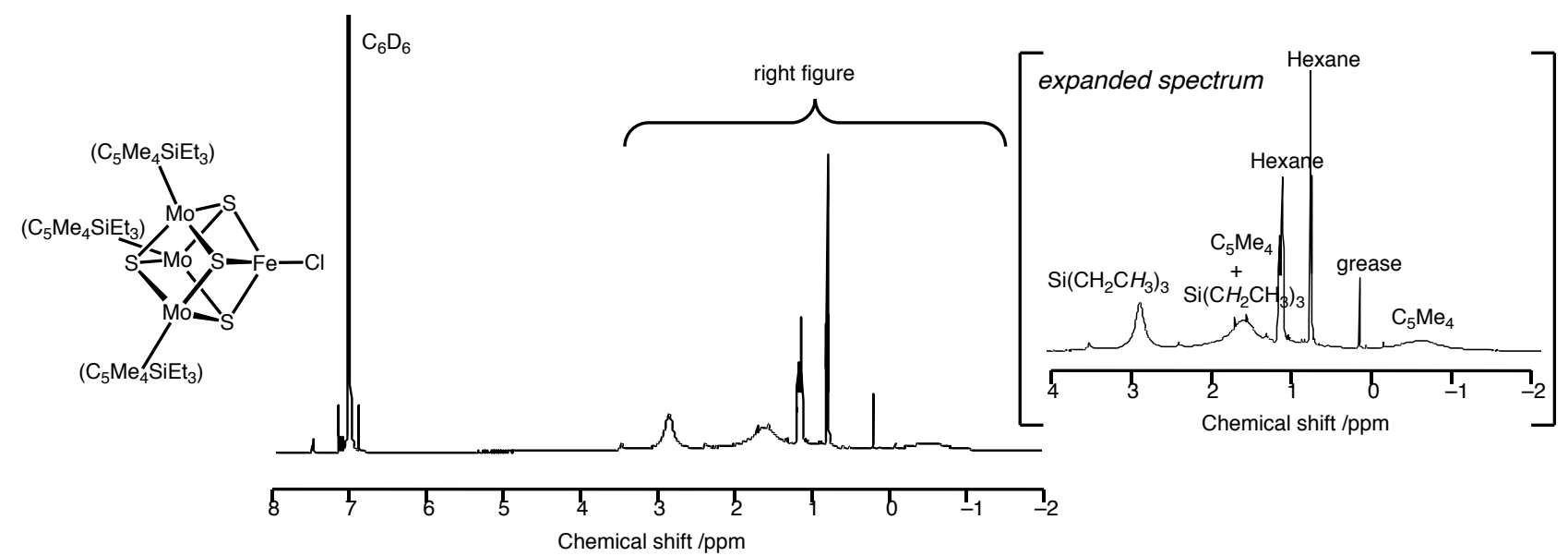

Figure S30 $\quad{ }^{1} \mathrm{H}$ NMR spectrum of $\left(\mathrm{C}_{5} \mathrm{Me}_{4} \mathrm{SiEt}_{3}\right)_{3} \mathrm{Mo}_{3} \mathrm{~S}_{4} \mathrm{FeCl}(\mathbf{5 b})$ in $\mathrm{C}_{6} \mathrm{D}_{6}$. 

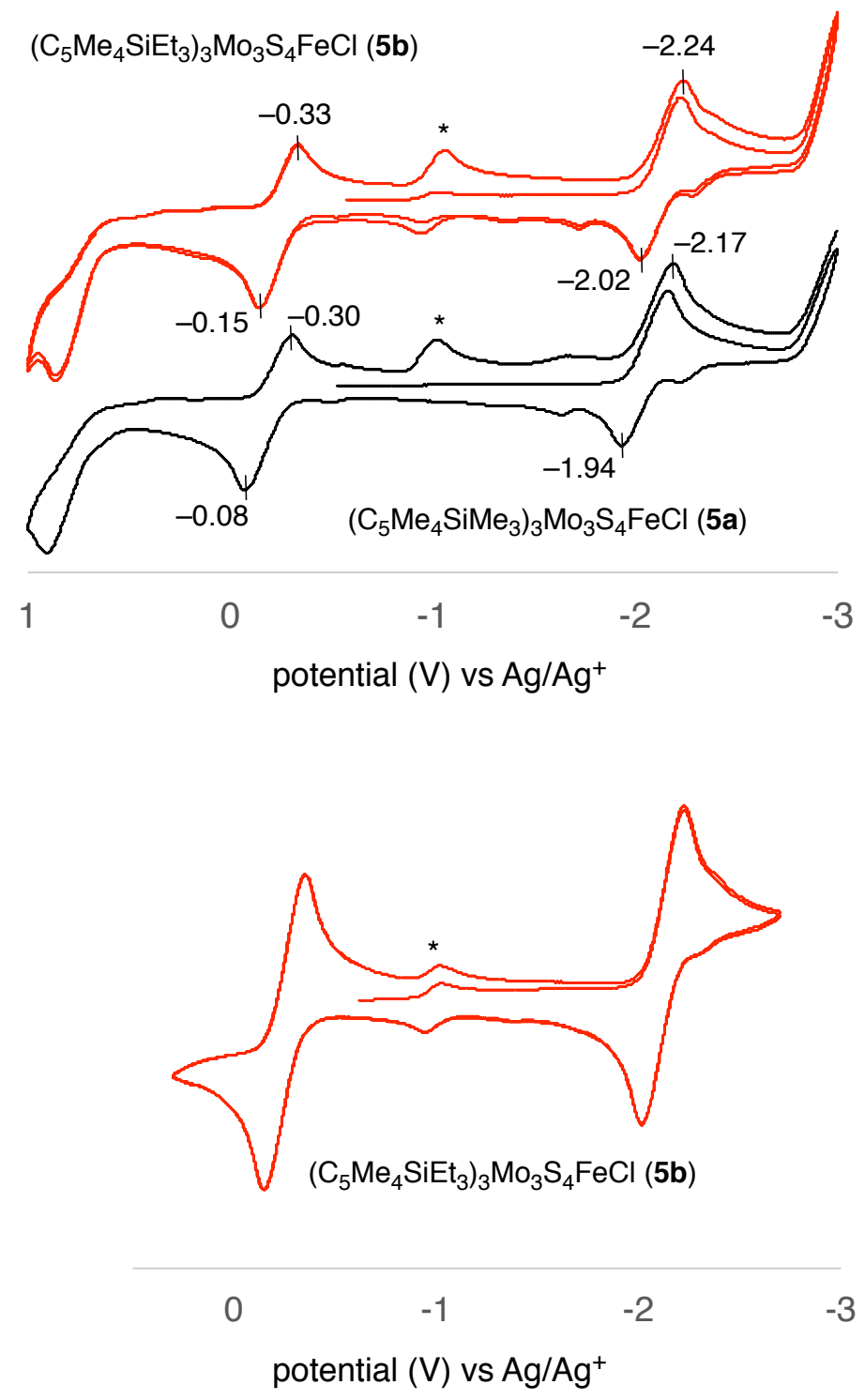

Figure S31 Cyclic voltammograms of $\mathbf{5 a}$ and $\mathbf{5 b}$ in THF at room temperature. Note that the peaks with $*$ appear after scanning to the region at around $+0.8 \mathrm{~V}$, and in fact the peak diminishes upon scanning in the narrower range (bottom figure). The peaks with * are assignable to the $\left[\mathrm{Cp}_{3}{ }_{3} \mathrm{Mo}_{3} \mathrm{~S}_{4}\right]^{+/ 0}$ redox couples, indicating that dissociation of the Fe atom is induced by oxidation at around $+0.8 \mathrm{~V}$. Dissociation of the Fe atom upon oxidation of the $\mathrm{C}_{5} \mathrm{Me}_{5}$ analogue has been reported (Y. Ohki, et al. Chem. Eur. J. 2018, 24, 17138-17147). Measurement conditions: scan rate $=0.1 \mathrm{~V} / \mathrm{s}$; concentration $=2.0 \mathrm{mM}$; concentration $\left(\left[{ }^{n} \mathrm{Bu}_{4} \mathrm{~N}\right]\left[\mathrm{PF}_{6}\right]\right)=0.2 \mathrm{M}$; working electrode $=$ glassy carbon; reference electrode $=\mathrm{Ag} / \mathrm{AgNO}_{3}$; counter electrode $=\mathrm{Pt}$. 


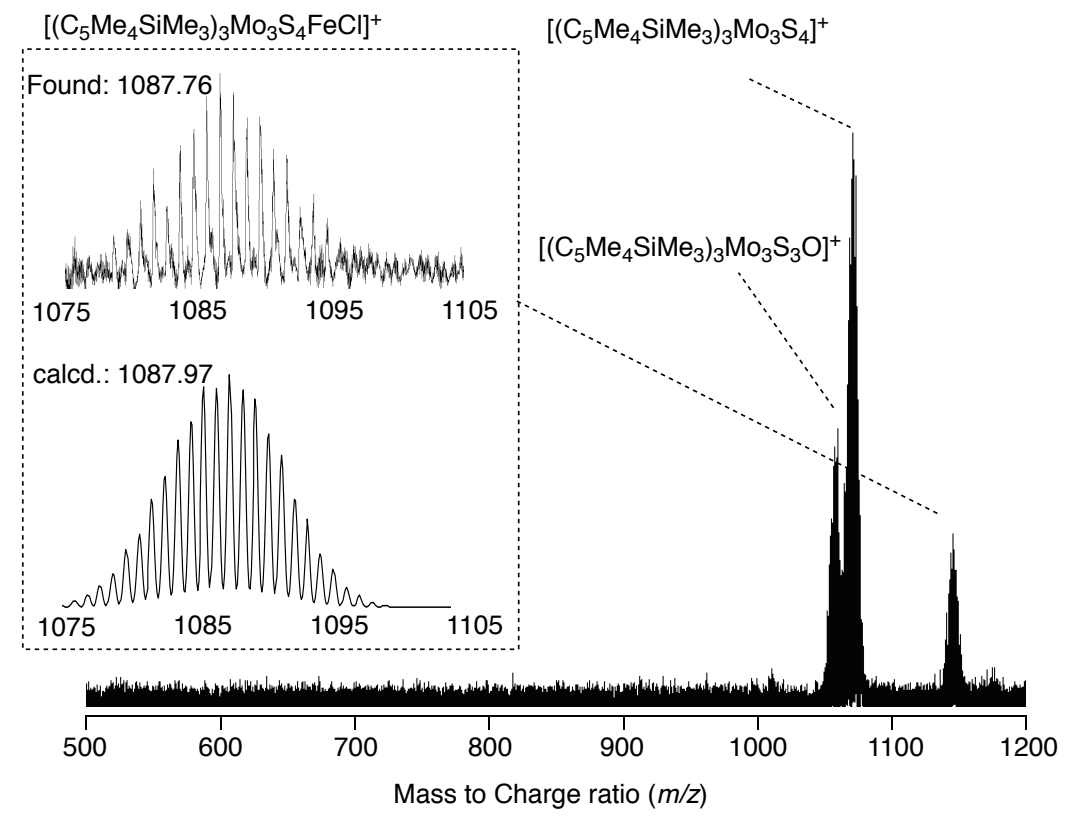

Figure S32 ESI-MS spectrum of 5a in THF at room temperature, showing an intense signal for $\left[\left(\mathrm{C}_{5} \mathrm{Me}_{4} \mathrm{SiMe}_{3}\right)_{3} \mathrm{Mo}_{3} \mathrm{~S}_{4}\right]^{+}$. Owing to the applied positive potentials in the spectrometer (as well as inevitable air exposure during the measurement), the cubic cluster possibly dissociates the Fe atom to generate the cationic species $\left[\left(\mathrm{C}_{5} \mathrm{Me}_{4} \mathrm{SiMe}_{3}\right)_{3} \mathrm{Mo}_{3} \mathrm{~S}_{4}\right]^{+}$. Air exposure should be the reason for the exchange of one of the sulfur atoms of $\left[\left(\mathrm{C}_{5} \mathrm{Me}_{4} \mathrm{SiMe}_{3}\right)_{3} \mathrm{Mo}_{3} \mathrm{~S}_{4}\right]^{+}$to give the signal of $\left[\left(\mathrm{C}_{5} \mathrm{Me}_{4} \mathrm{SiMe}_{3}\right)_{3} \mathrm{Mo}_{3} \mathrm{~S}_{3} \mathrm{O}\right]^{+}$, which also appears in the spectrum of $\mathbf{3 a}$ (Figure $\mathrm{S} 18$ ). 


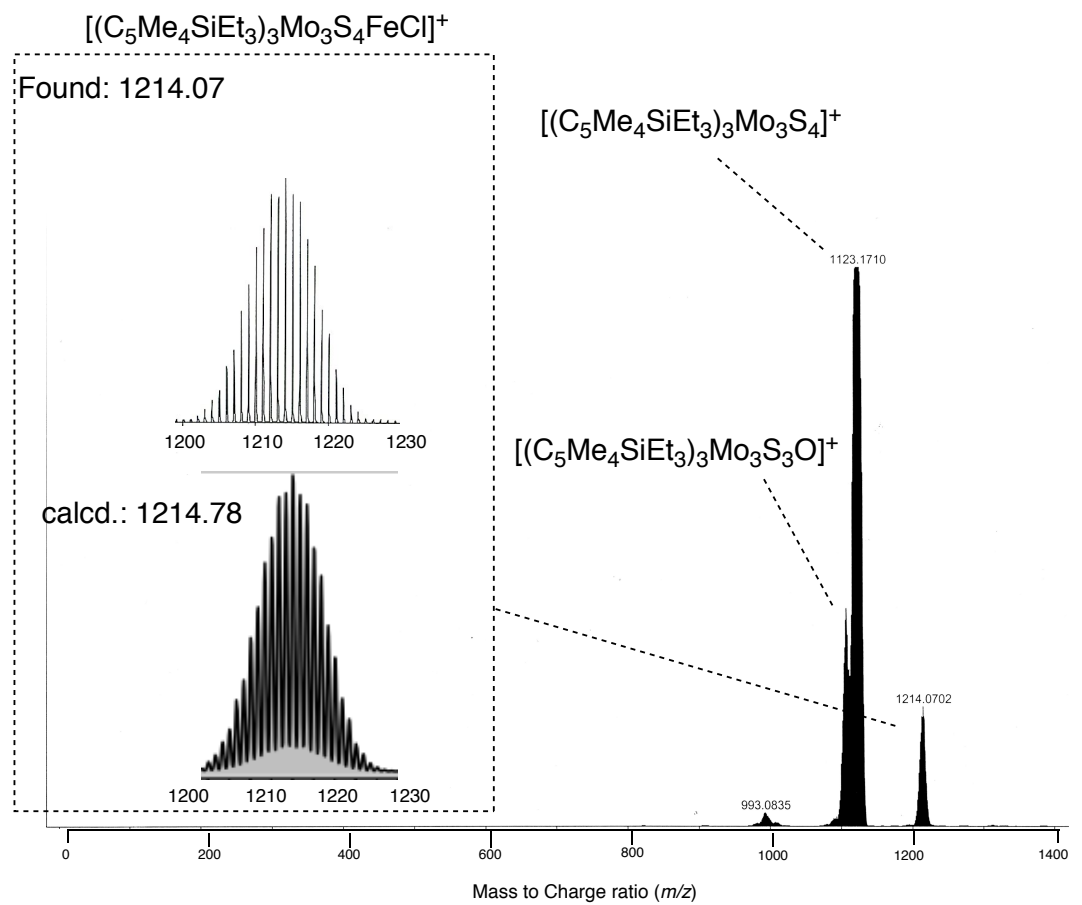

Figure S33 ESI-MS spectrum of $\mathbf{5 b}$ in THF at room temperature, showing an intense signal for $\left[\left(\mathrm{C}_{5} \mathrm{Me}_{4} \mathrm{SiEt}_{3}\right)_{3} \mathrm{Mo}_{3} \mathrm{~S}_{4}\right]^{+}$. Owing to the applied positive potentials in the spectrometer (as well as inevitable air exposure during the measurement), the cubic cluster possibly dissociates the Fe atom to generate the cationic species $\left[\left(\mathrm{C}_{5} \mathrm{Me}_{4} \mathrm{SiEt}_{3}\right)_{3} \mathrm{Mo}_{3} \mathrm{~S}_{4}\right]^{+}$. Air exposure should be the reason for the exchange of one of the sulfur atoms of $\left[\left(\mathrm{C}_{5} \mathrm{Me}_{4} \mathrm{SiEt}_{3}\right)_{3} \mathrm{Mo}_{3} \mathrm{~S}_{4}\right]^{+}$to give the signal of $\left[\left(\mathrm{C}_{5} \mathrm{Me}_{4} \mathrm{SiEt}_{3}\right)_{3} \mathrm{Mo}_{3} \mathrm{~S}_{3} \mathrm{O}\right]^{+}$, which also appears in the spectrum of $\mathbf{3 b}$ (Figure $\left.\mathrm{S} 19\right)$. 


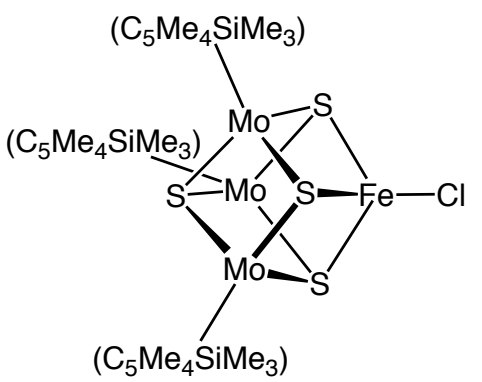

$5 a$

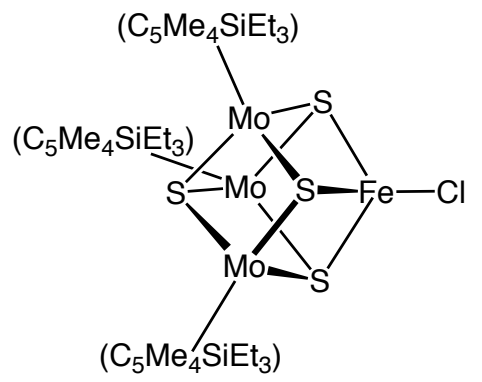

$5 \mathbf{b}$
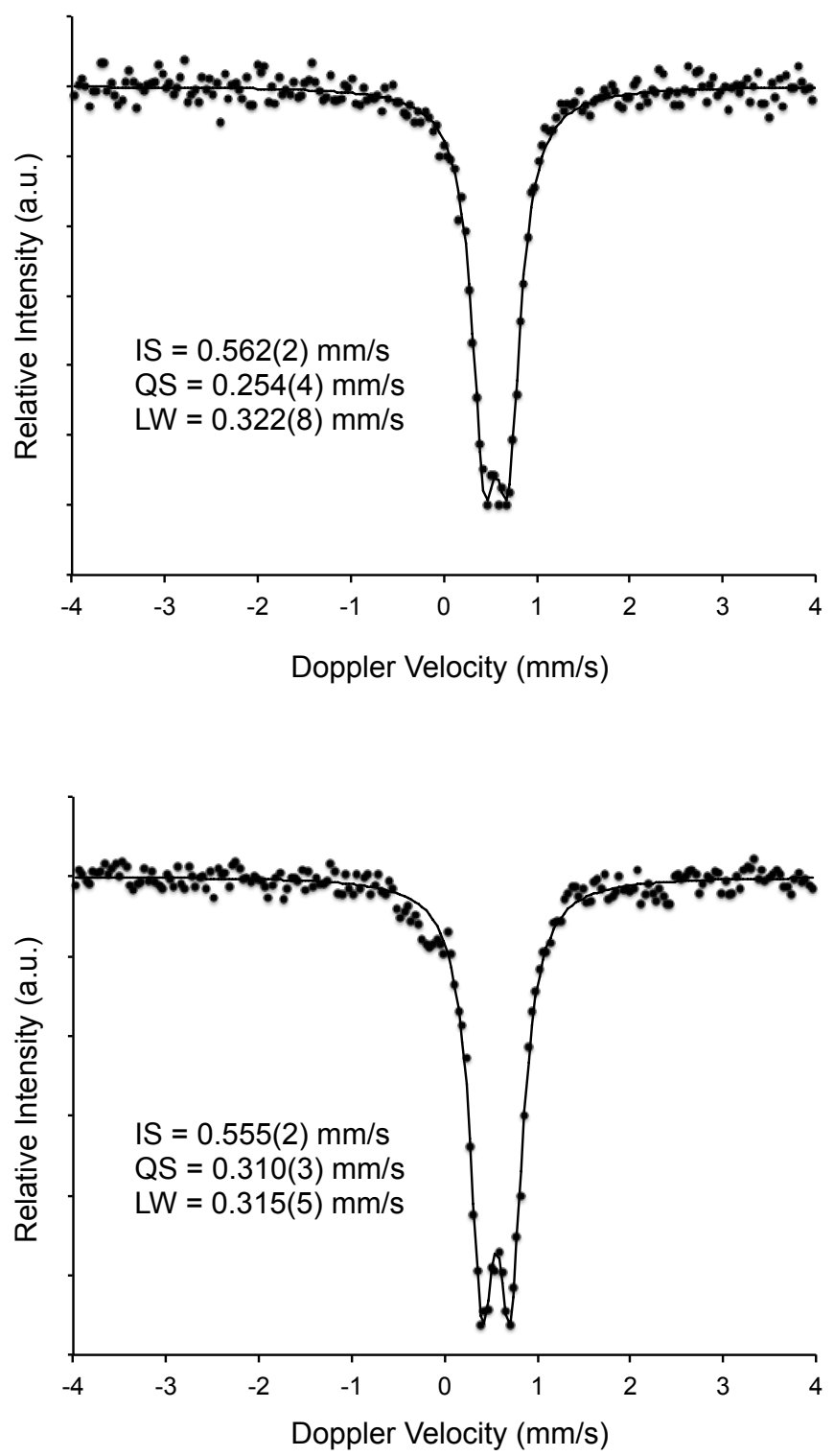

Figure S34 Mössbauer spectra of polycrystalline 5a and $\mathbf{5 b}$ at zero field and $78 \mathrm{~K}$. The Doppler velocity scale was calibrated by using the room-temperature Mössbauer spectrum of $\alpha$-iron foil. 